\title{
Virumaa talurahva aineline kultuur 19. sajandil ja 20. sajandi alguses
}

\begin{abstract}
Edgar Saar
Teesid: Alljärgnevas Virumaa ainelise kultuuri ülevaates on tähelepanu pööratud muutuste esiletoomisele elamuehituses, interjööris, maaharimisviisides ja karjakasvatuses. Iseloomustatud on kalapüügitraditsioone Peipsi järvel ja Viru rannikumerel ning vanu küttimisviise ja talurahvakaubandust. Eraldi rubriigis käsitletakse tavanditoite, rõivastust ning kodukäsitööd, puutööharrastuses on esil Tudulinna piirkond.
\end{abstract}

Märksõnad: elatusalad, kauplemine, rõivas, taluhooned, toit, Virumaa

\section{Külad}

Virumaal oli 19. sajandil kõige enam levinud külatüübiks sumbküla, esines ka rida-, ahel-, haja-, ring- ja tänavkülasid. Sumbkülas asetsevad talud kobaras koos, ridakülas ridastikku piki teed, põlluserva, mäeveeru või veekogu kallast. Ahelkülas paiknevad talud ridastikku, mõningate vahemaadega üksteisest eemal. Ringkülas on talud ringjalt. Tänavkülas on talud tihedalt kahel pool tänavat. 19. sajandil oli sumbküla näiteks Hulja (Kadrina), ridaküla Aidu (Lüganuse), ahelküla Salutaguse (Simuna), ringküla Võipere (Haljala), hajaküla Kuusikmäe (Viru-Nigula) ja tänavküla Vasknarva (Vaivara). Tänavkülad olid Peipsi põhjakaldal ja Narva jõe ääres vene elanikonnaga aladel. (ERKL 117-118)

19. sajandi teisel poolel ja 20. sajandi algul toimus Eestis talude kruntimine. Ka Virumaal koondati talude põllumaad, mis enne kruntimist olid lappide ja ribadena laiali, kokku üheks tervikuks, kuhu kuulus ka taluõu. Külade ühised karja- ja heinamaad jaotati taludele ära. Kruntimine tõi kaasa külade asustuse hajutamise. Rohkesti tekkis üksiktalusid. Kruntimisega samaaegselt toimus talude päriseksostmine. Talude kruntimise ja päriseksostmisega kaasnesid suured muudatused talurahva ühiskondlikus elus, majanduses ja elu-olus. (Moora 1964: 65-101; Troska 1987; EA V: 130-138) 


\section{Elumaja ja selle sisustus}

Talurahva elumajaks on sajandeid olnud rehielamu, mis koosnes rehetoast, rehealusest ja ühest või mitmest kambrist. Virumaal oli rehielamu Põhja-Eesti tüüpi, kuigi esinesid ka mõned Lõuna- ja Lääne-Eesti tüüpi rehielamud. PõhjaEesti tüübil oli rehetuba kõrgem ja kitsam kui rehealune. Rehetuba piirasid neljast küljest mitmeotstarbelised madalamad ruumid. Eespool oli koda ja sahver, tagapool aganik, ühes otsas oli rehealune, teises kamber (kambrid). Rehetoal puudusid aknad, ta oli kehvasti valgustatud, aga kaitstud külma tuule eest, seetõttu soe. Mainitud rehielamuga samaaegselt esines tihti selliseid hooneid, kus rehetoa ees oli lai ulualune ning rehetoa seinas aknaavad. (Tihase 1974: 116-126; Pärdi 2012: 25-50)

Taluhoonete seinad ehitati tavaliselt männi- või kuusepuust. Kuni 19. sajandi keskpaigani raiuti ehituspuud ning ehitati hooned kirve abil. Andmeid suursae kasutamise kohta eestlastel on 18. sajandist, enam levis see siiski 19. sajandi keskpaigas. Taluhoonete katusematerjaliks olid õled. Lagi tehti rehielamul ümarpalkidest, mis olid peenemad kui seinapalgid. Rehetoast viis uks rehealusesse ja teiselt poolt kambrisse. Põrandad olid savist, paerikastel aladel kivist. Savipõranda tegemisel võeti ära pinnase pealmine kiht, tasandati ning tambiti põrand kõvaks. Sageli tihendati seda sissetambitud kruusa või kividega, millele asetati liiva ja veega segatud savi.

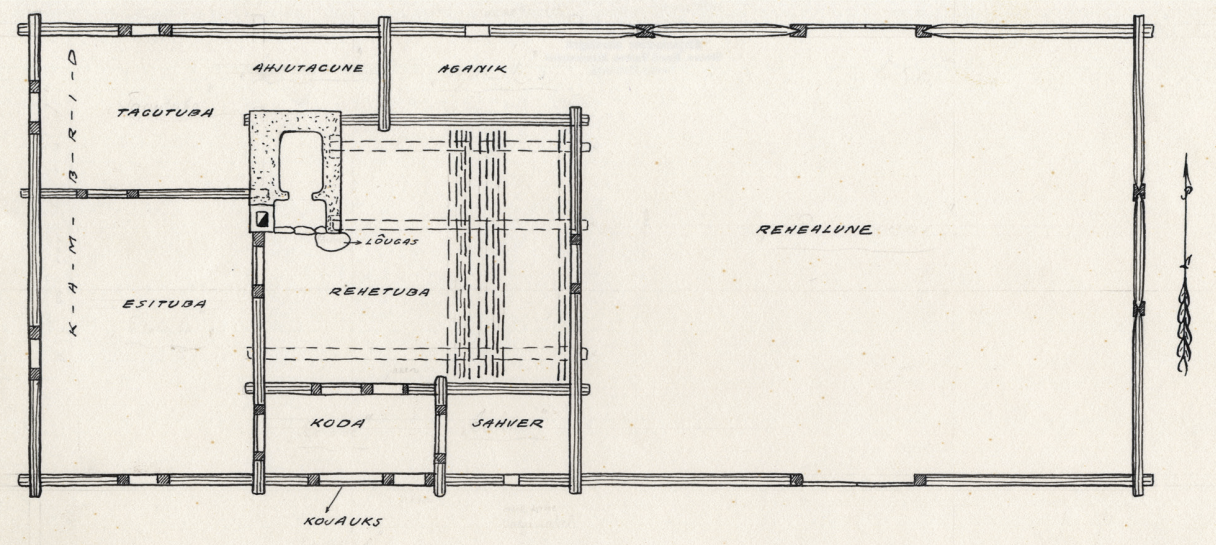

Joonis 1. Rehielamu põhiplaan. Väike-Maarja khk Koonu küla Uuetoa talu. E. Kitsingu joonis 1939. EJ 135:46. 


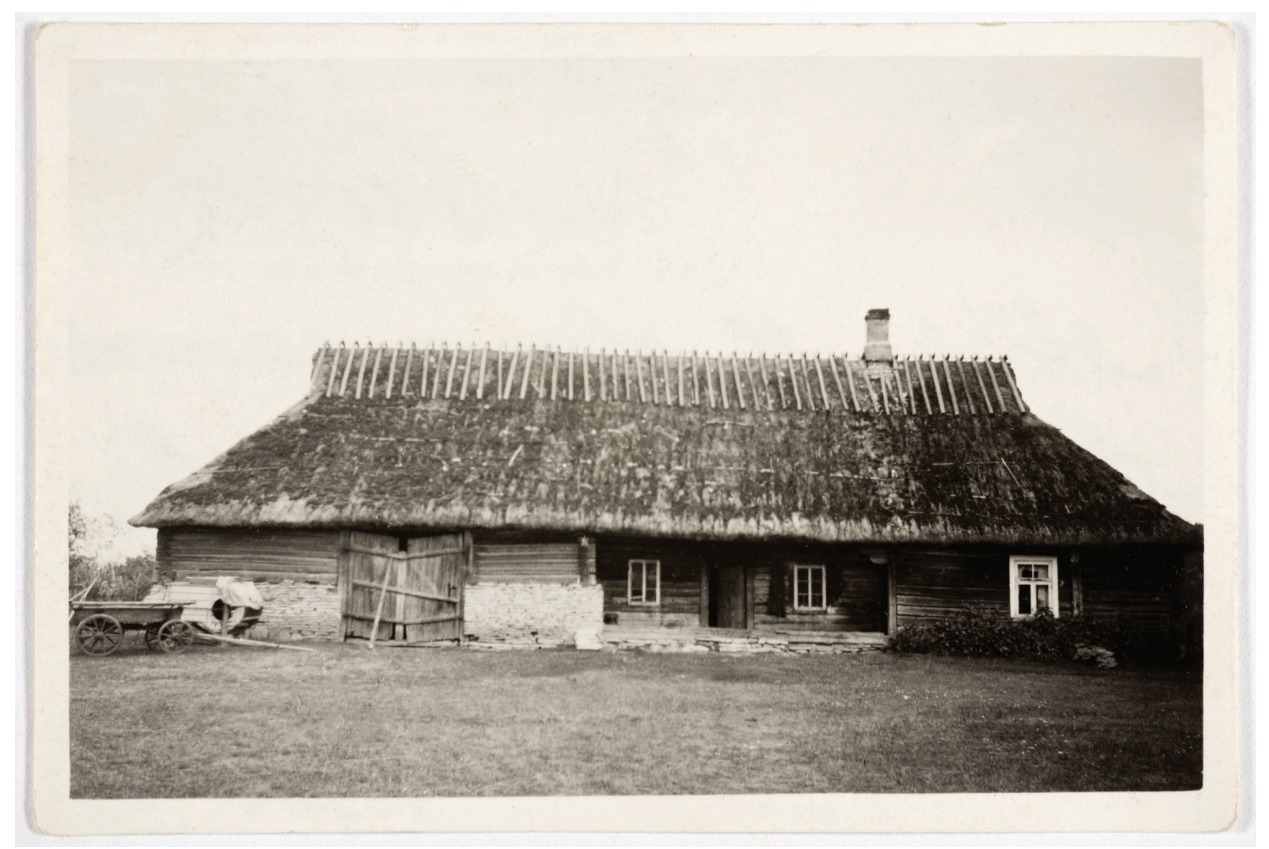

Foto 1. Rehielamu. Haljala khk Kasepää (Rutja) küla Möldre talu. E. Kitsingu foto 1938. Fk 830:72.

Rehetoa kambripoolses küljes oli paekivist ahi. Üldiselt olid Virumaal ahjud kerisega, esines ka umbahje. Kerisega ahjul oli tulepesa kohale kuhjatud kivikuhelik - keris. Tuli ja suits tulid läbi kerise, kuumendasid seda. Ruum soojenes mitte ahju seinte, vaid kerise kaudu. Kerisekive kandsid võlvkaared. Vanemad ahjud olid lahtise kerisega, hiljem asetati kerise kohale paekivist plaat või võlviti kividest ahjulagi. Ahju esiosas oli lahtine kolle - lee, kus keedeti toitu. Pada riputati kolde kohale puust pajakoogu või rauast ahelikuga. Ahju ees oli pae- või raudkivist iste - lõugas. Kuni 19. sajandi teise pooleni rehielamutel korstnat ei olnud. (Viires 1962; Pärdi 2012; Tihase 1974: 172-184; ERKL: 248, 250)

Suits lasti ikka uksest välja. Et suitsutuba külma eest hoida, oli vanast uks kahekordne. Välimine oli auguga [umbes 2 jalga] ukse ülemises pooles. Seda hüüti sangaks. Seesmine uks (mis tuppa lahti käis) oli päeva ajal ikka lahti. Sanga august läks suits välja, külm aga ei pääsenud tuppa tulema. Siit august tuli ka valgust. Pääle selle oli rehetoal veel rõppan: väike [poole jala suurune] auk lükatava luugiga. Siit läks väiksem suits välja (Haljala). 


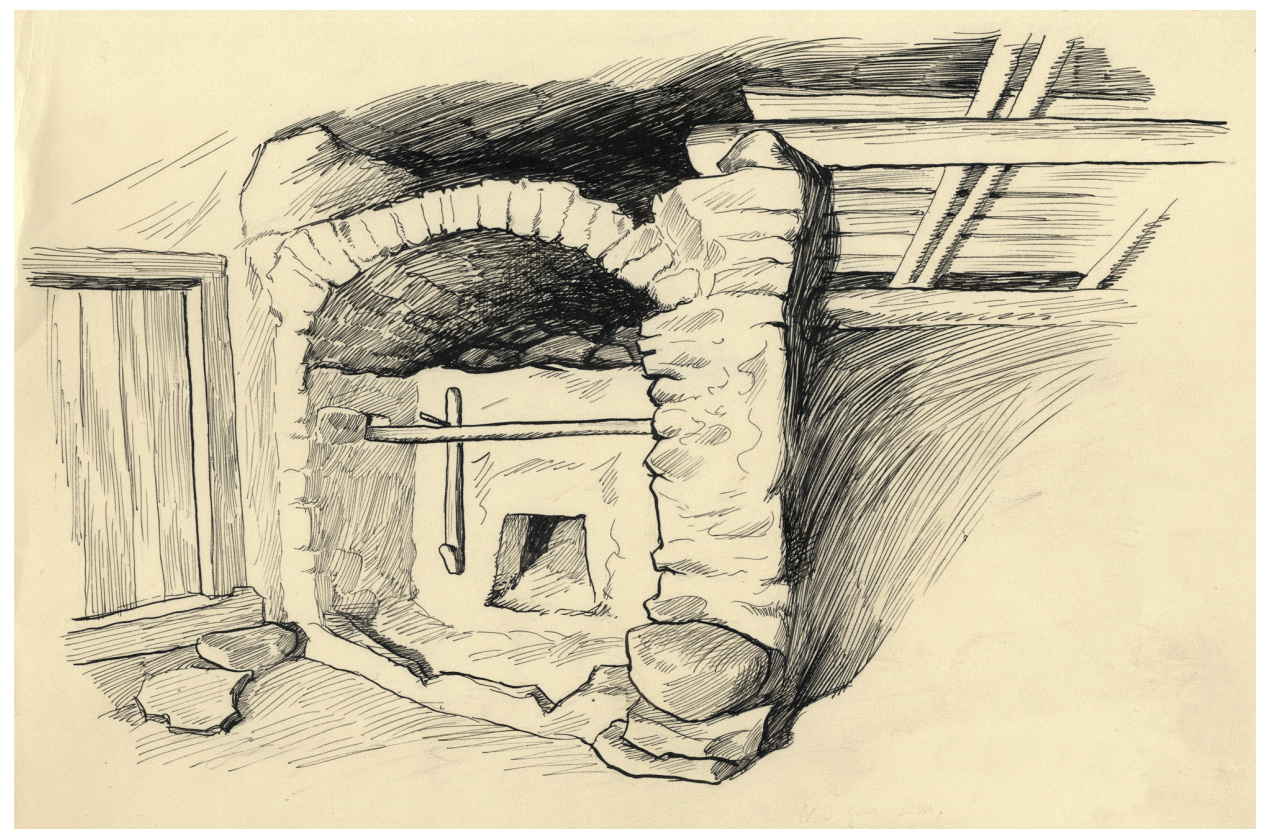

Joonis 2. Rehetoa kummiga kaetud kerisahi. Viru-Jaagupi khk Leo küla Abrami talu. I. Linnati joonis 1937. EJ 84:62.

Oli ka selliseid uksi, kus seespool oli täisuks, väljaspool pooluks, mis sulges ukseava alumise osa. Suitsu väljalaskmiseks avati täisuks.

Rehetoa sees olid piki hoonet asetsevatele taladele ristipidi asetatud peenemad palgid - parred, millel kuivatati sügisel vilja. Nende arv oli 9-18.

Rehetuba oli pere talviseks elu- ja tööruumiks. Suvel magati kambris, aidas, lakas või küünis, toitu valmistati suveköögis. Rehetoa sisustus oli lihtne. Tagaseina ääres, ahju ja rehealuse seina vahelises osas või siis rehetoa ühes nurgas oli magamislava või säng. Magati ka ahju peal ja partel. Seina ääres olid pikad pingid, kus vajaduse korral ka magati. Söögilaud oli keset tuba, või akna all, kui rehetoal oli aken. Vanemad lauad olid ristjalgadega, millel lauaplaat oli lahtiselt, uuemad lauaplaadid tapitud jalgadega. Istuti pinkidel või järidel, mis olid kolme või nelja jalaga. Toole oli taludes 19. sajandi esimesel poolel vähe, sajandi teisel poolel ning eriti lõpus suurenes nende kasutamine. (Tihase 1974: 176-184; ERK: 252-257)

Igal perekonna liikmel oli oma isiklik kindel lusikas. Leiva ja liha lõikamiseks tarvitati küla seppa tehtud pussi. Mõnes peres oli olemas liigetega nuga, mida harja ja räbala kaupmehed külas mü̈̈sid. Toitu pakuti lauale ühe suure puuvaagnaga, kust siis iga perekonna liige oma lusikaga 
Foto 2. Rehetoa pool-ja täisuks. Jõhvi khk Metsküla Uuetoa talu. T. Pedaku foto 1960. Fk 1317:95.

toitu võttis ja suhu pistis, nii kaua kui kõht täis sai. Kuivad toidud, kartul, kaalikad, naeris, liha, silgud ja muud söödi palja käega ja lakuti sõrmed rasvast ilusti puhtaks (Viru-Nigula, KV 91).

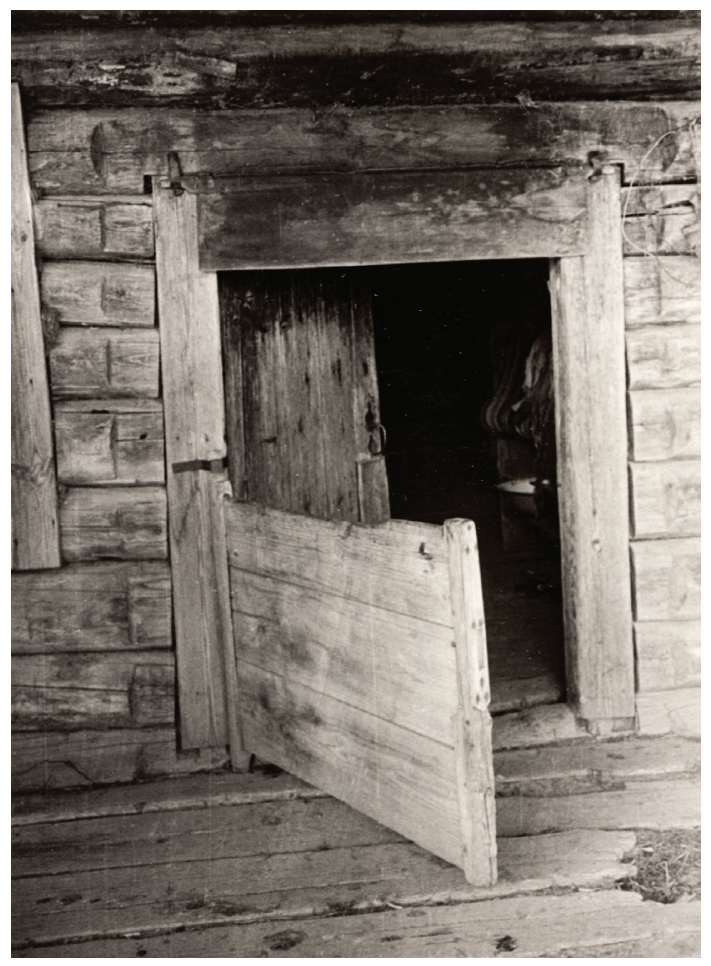

Väikelapse jaoks oli häll. Vibuhällid on vanemat ja jalashällid uuemat tüüpi. Riideesemeid, kangaid ja ehteid hoiti kirstudes. Tavaliselt oli talus mitu kirstu, need asusid harilikult aidas, aga ka kambris. Rehetuba valgustati põlevate peergudega. Peeru ots pisteti tulejala ülaosas oleva pilaku vahele. Mõnel pool oli pilak kinnitatud reheahju külge. Pidulikel juhtudel (jõulud, pulmad) kasutati küünlaid. 19. sajandi viimastel aastakümnetel tulid petrooleumilambid. Kuni tuletikkude kasutuselevõtuni tehti tuld tuleraua, tulekivi ja taelaga. Tulerauaga löödi vastu tulekivi, tekkisid sädemed, mis süütasid taela. Tavaliselt oli selleks puuseene (tuletaela Fomes fomentarius) kuivatatud viljakeha. Et taela küljest tuld saada, pandi see süte või õlgede vahele ning puhuti peale. (ERKL: 315-316; ERK: 252-257)

Talvel külmaga toodi ajutiselt rehetuppa koduloomi, sagedamini kanu, aga ka vastsündinud või haigeid tallesid, vasikaid ja põrsaid, vahel ka täiskasvanud loomi. (Jaagosild 1965; ERKL: 250)

19. sajandi teise poole rehielamut iseloomustavad mitmed muutused. Klaasakendega rehielamutest on andmeid juba sajandi algusest, üldiseks said need sajandi keskel. Rehielamul, millel rehetuba oli teiste ruumidega piiratud kolmest küljest, tehti aken vabasse välisseina. Kus rehetuba oli teiste ruumidega ümbritsetud neljast küljest, tehti aken koja ja esikülje seina. Muutusid 
kütte- ja keedukolded. Kinnise kerisega ahju kerisepealsesse ahjumüüri tehti auk. Pärast ahju kütmist see avati, soe õhk läks kambrisse. Rehetuppa ja ka kambritesse hakati pliite ehitama. Rehielamu sai köögi. Pliidi juurde ehitati soemüür (soojalõõr, truup), mis soojendas kambrit; suits juhiti soemüüri lõõride kaudu rehetuppa, kust see uksest ja leitseaugust välja lasti. Seega muutusid kambrid suitsuvabaks ja köetavaks. (Viires 1962; Pärdi 2012)

1881. aastal oli Virumaal korstnateta taluelamutes suitsuvabasid kambreid 35,5\%. Kadrina ja Väike-Maarja kihelkonnas oli neid üle 60\%. (Kogu Eestimaa kubermangus oli sel viisil köetavaid korstnateta taluelamuid 30,7\%.) 19. sajandi teisel poolel ehitati taluelamutele rohkesti korstnaid. 1881. aastal oli korstnatega taluelamuid Virumaal 38,6\% (kubermangus 24,9\%). Virumaal oli neid rohkem idapoolsetes kihelkondades: Vaivaras 92,2\%, Jõhvis üle 70\% ning Iisakus üle 60\%. Alla 30\% oli Kadrina ja 20\% Väike-Maarja kihelkonnas. Aga, nagu juba mainitud, oli seal rohkesti köetavaid suitsuvabasid kambreid. (Viires 1962: 101-104; Pärdi 2012)

19. sajandi teisel poolel hakati taluhooneid laialdaselt katma laast- ja sindelkatustega. Siiski, 1881. aastal oli õlg veel Eesti taluelamutel enim kasutatav kattematerjal. Virumaal oli mainitud aastal õlgkatuseid 78,6\% ning puitkatuseid (laast, sindel, laud) $17,8 \%$. Virumaal oli puitkatuseid enam Vaivaras 51,4 \%, Jõhvis ja Simunas üle 20\%, mujal vähem. (Võrdluseks: 1922. aastal oli maakonnas puitkatuseid 46,7\%, õlgkatuseid 45\%). Seoses kambrite köetavusega hakati rehielamutele ehitama laudpõrandaid, eeskätt kambritele. (Viires 1962; Pärdi 2012)

Talupere eeliseluruumideks said kambrid.

Eeskambris aiapoolse akna all seisis pikk laud pinkidega. Seal söödi siis, kui oli rohkem tööperet või tuli pühapäeval külalisi. Teise akna juurde asetati kangasteljed, kui kuduma hakati. Talvel oli aga kogu elamineolemine tagakambris ja väikeses köögis. Tagakambris magati. Seal seisid ka vokid, mis jälle vurisema hakkasid, kui talitused loomadega valmis said (Haljala).

19. sajandi viimastel aastakümnetel ehitati üha enam elamuid rehest eraldi. Rohkem hakati tarvitama tislerite tehtud kappe, voodeid, laudu, toole, ilmusid kummutid, osteti seinakelli, levisid Lutheri vabriku ning avinurmikute toolid.

\section{Kõrvalhooned}

Peale elamu olid taluõues kõrvalhooned: suveköök, ait, saun, laut, kelder; nendes taludes, kus tehti sepatööd, oli ka sepikoda. Suveköögid olid kahesugused: ühed olid püstkojad, teised nelinurksed ehitused. Püstkoda oli ehitatud koo- 


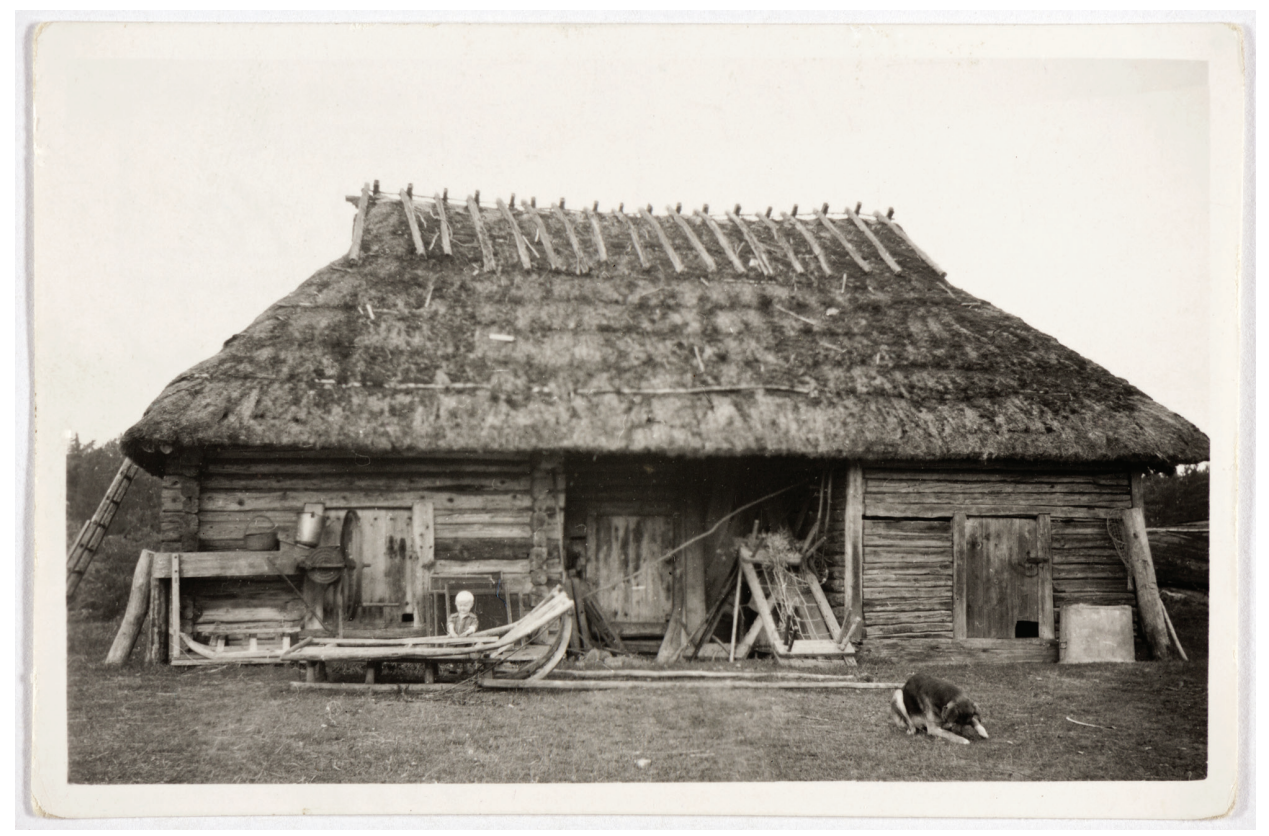

Foto 3. Aidad. Haljala khk Kasepää (Rutja) küla Möldre talu. E. Kitsingu foto 1938. Fk 830:70.

nusekujuliselt asetatud lattidest, katteks kasetohtu, kuusekoort ja mättaid. (Tihase 1974: 245-248)

Õueküäk ja suveküäk, kuda tädä kutsuti. Noh, sie õli lattidest. Sie õli sedasi, et kaks latti siuti estest ülävält paari ja alt siis tõmmeti laijali nied latti ôtsad, nindat üläs jäi rist. No siis pandi lattid kahele puale neije vasta ja siis akketi teibaid ümbär lautima. Nindat kõhe paksult pandi neid teibaid, nindat ikke sies, kui õlid, siis õue ei nähänd. Ukse auk jääti kaa. Ukse pääl õli põigite latt lüädud ja teibad akketi siis senest lattist üläs menema, õtsad õlivad sene latti küljäs. Sies ei ôld muud midagi, kui kaks arki õli püsti ja üks latt õli neije aarude vahel ja see pada rippus sangapidi sääl latti küljäs ja alle tehti siis tuli ja siis keideti. A sie sang õli pikk, muidu tuli põletas sene latti läbi, kui madalamal õli, ja kõrgel ei akkand pada usina kiema. Suvel ólivad sääl keitaned, et reijetuas ei taha, et suits, ja liiga suajast lähäb (Jõhvi). (Pajatusi: 128)

Nelinurksed suveköögid ehitati palkidest, põhjarannikul ka paekivist. Suveköökides oli lahtine tulekolle, siin keedeti suvel toitu. Kui elumajadesse ehitati korstnad ja köögid, ei olnud suveköögid enam vajalikud ning aja jooksul nende ehitamisest loobuti. (Tihase 1974: 250-255) 


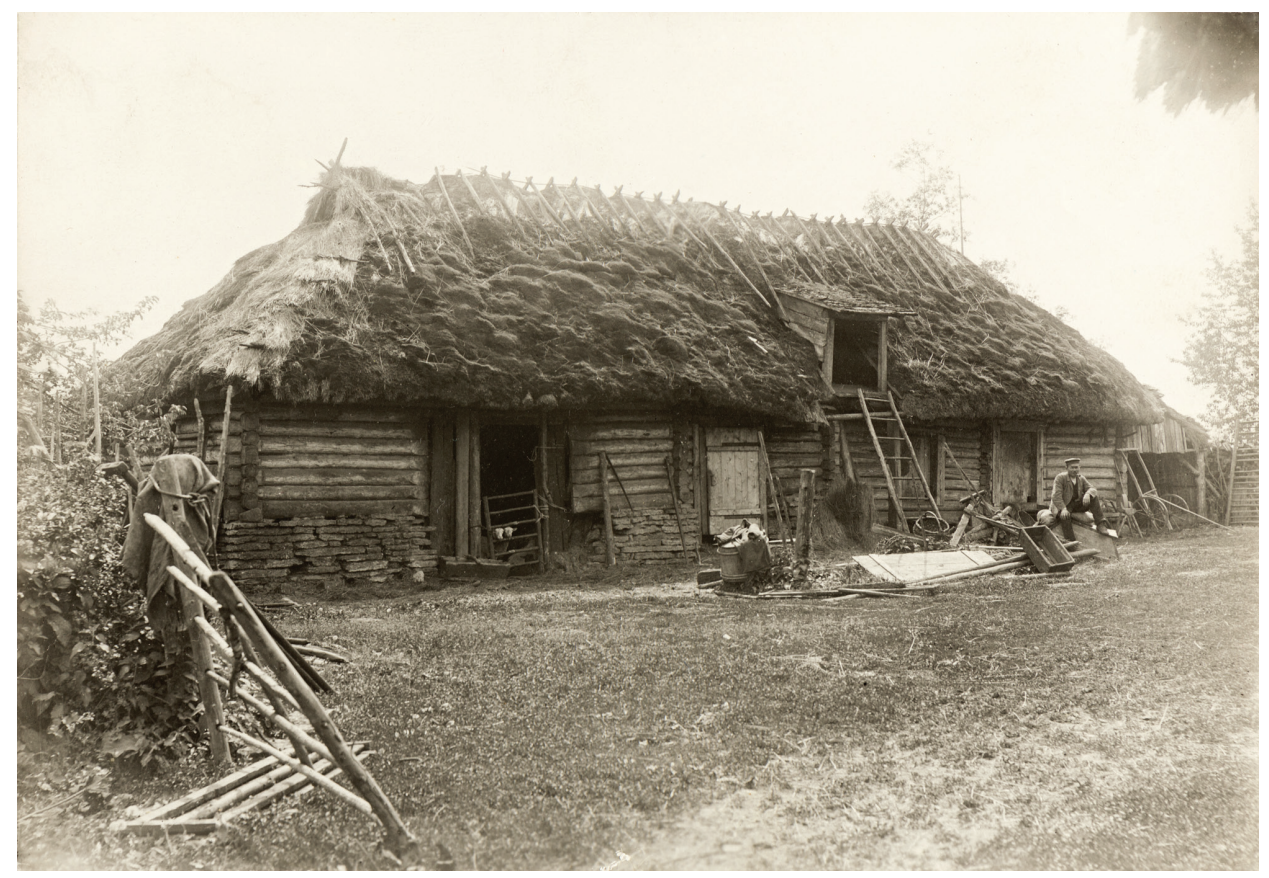

Foto 4. Laut. Jõhvi khk Pühajõe küla Kreismanni talu. J. Pääsukese foto 1913. Fk 214:59.

Tähtsaks majandushooneks oli ait. Sageli oli talus kaks aita, mõnel pool kolm. Üks oli vilja, teine liha-kala ja kolmas riiete ait. Viimases magati ka suvel. Ait ehitati ümarpalkidest. Nurkade toeks olid kivid, et tuul hoone alt läbi käiks. Uksenurgas oli kassiauk. Palkidest ehitati ka saun. Selles oli vihtlemislava ja kerisega ahi. Kõikidel taludel ei olnud sauna - viheldi rehetoas. Laut ehitati palkidest, Viru rannikul ka paekivist. Vanematel lautadel oli tihti ühes otsas veise-, teises lamba- ja sealaut. Hobuseid hoiti 19. sajandil rehealuses, aga seal peeti ka teisi loomi. Lauda lakka pandi heinu ja põhku. Vanemad laudad olid akendeta. 19. sajandi lõpul ja 20. sajandi algul ehitati suuremaid klaasitud akendega lautu. (Tihase 1974: 256-281)

Kartulite hoidmiseks oli kivist või palkidest kelder, mis asetses poolest saadik maa sees. Selle laele visati paks mullakiht. Kui varem olid kiviseintega keldrid palklagedega, siis 19. sajandi teisel poolel hakati ehitama ka võlvlagedega keldreid. Talule vajalik vesi toodi kaevust. Kaevud olid kas kivide või puudega vooderdatud ning ka maa peal ümbritseti need kas kivi- või puuraketega. Madalast kaevust võeti vett lati külge kinnitatud kapa või ämbriga, sügavamast vinna või võlli abil. (Tihase 1974: 281-291) 


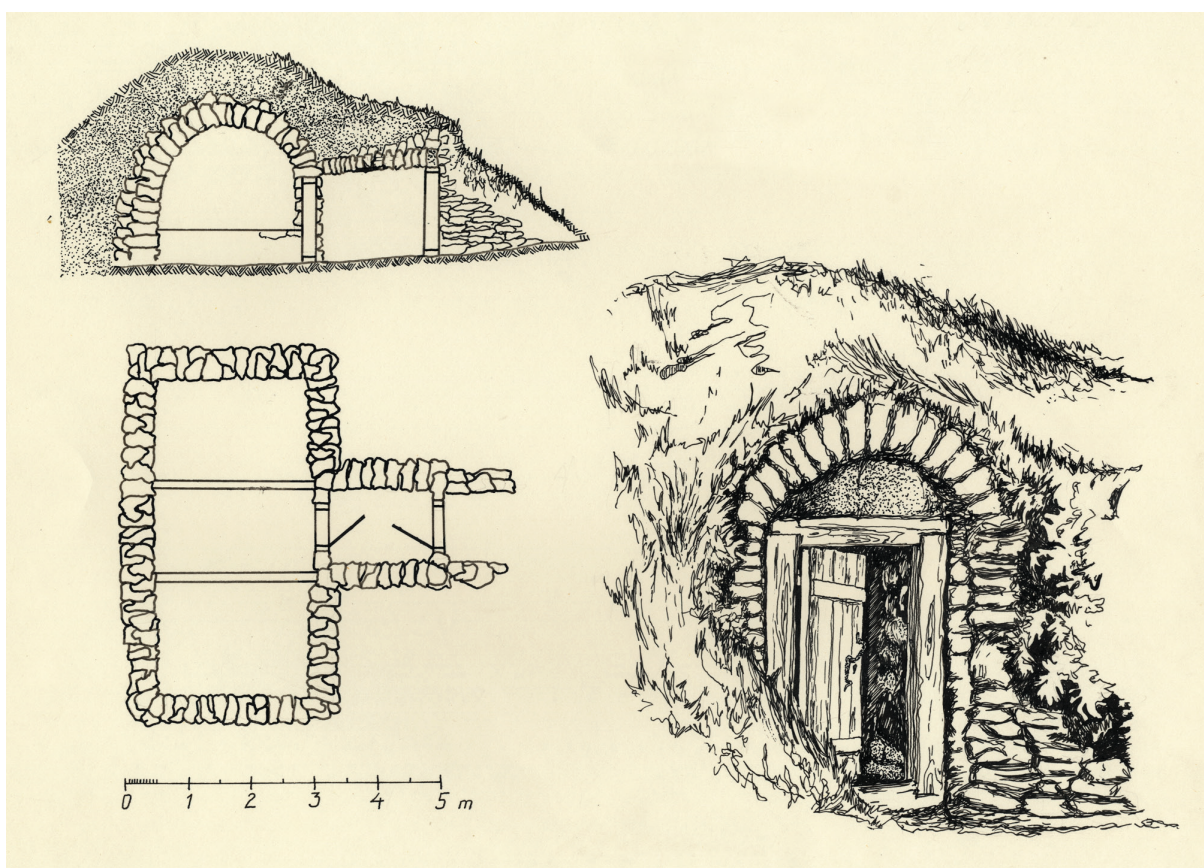

Joonis 3. Kelder. Haljala khk Idavere küla Mihkli talu.

A. Hermanni joonis 1977. EJ 360:1.

Joonis 4. Kaev. Iisaku khk Pikati küla Lugavälja talu. I. Linnati joonis 1937. EJ 84:37.

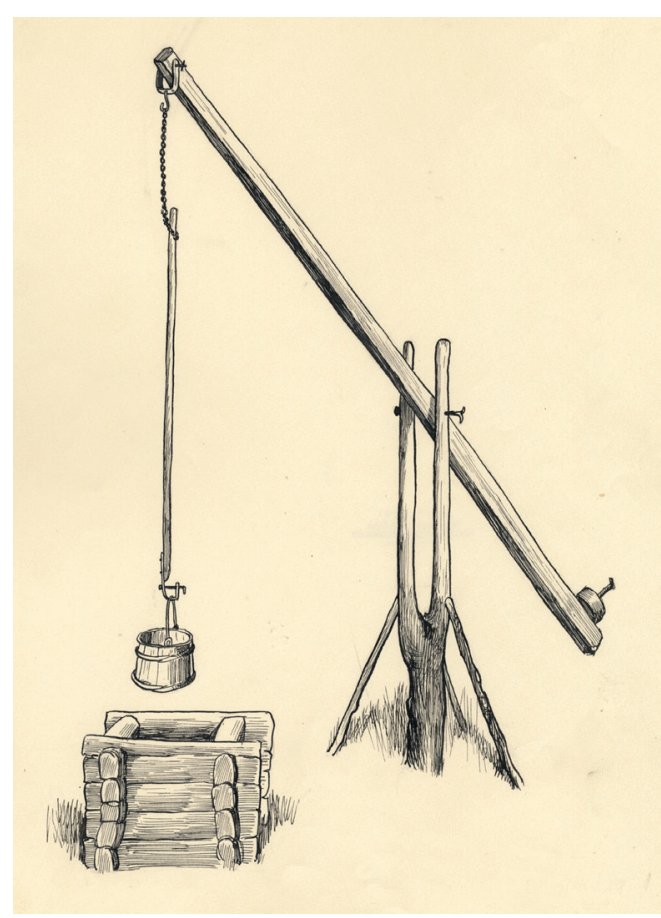




\section{Põllundus}

Virumaalaste põhiliseks elatusallikaks on olnud põllundus. Kasvatati rukist, otra, nisu ja kaera, aga ka herneid, ube, läätsi, naereid, kapsaid ja kaalikaid. Kui kartulid olid 19. sajandi esimesel veerandil aiamaal, siis teisel veerandil kasvatati neid juba põldudel. Kartulikasvatus laienes 19. sajandi viimastel aastakümnetel, mil veeti kartulit Virumaalt Peterburi ja Soome. Sajandi lõpus levis taludes porgandi, sibula, lillkapsa, aedoa, kõrvitsa ja siguri kasvatamine. Rohkesti kasvatasid sibulaid Peipsi-äärsed venelased, kes käisid neid vilja vastu vahetamas peaaegu kogu Mandri-Eestis, nende kaubareisid ulatusid Lääne- ja Pärnumaale. (Moora 1980: 5-31; EA V: 115-117)

Põlde väetati sõnnikuga, mis põldudele veeti tavaliselt talgutega.

Ennemast, mis õlivad siin kõige suuremad talgud, õlivad sõnniku talgud. Ükski pere ei vedand ilma talgudeta oma sõnniku vällä. Iga kevade läks kaks päivä sõnniku talgudega. Kakstõist miest õli iga kevade talgul, vahel viel nelitõist miest. Neil õli vaja igaühäl vastas talgul kaa käijä. Sääl õli siis viel vedajad ja mahalaskejad ja lahutajad ôlid viel erid. No kuuskaheksa obust siis ôli. Talgulised õlivad ikke naaburist ja kaugemalt kaa sugulased ja. Tütrikud olid siis lahutajad, lahutasivad väljäl ja. Vedajad ôlivad poisikesed ja lapsukesed. Mahalaskeja õli mies [---]. Vahest võeti kolmest kõhast kõrraga sõnniku. Lautast, sia aijast ja obuse sarast vai riijalast, kus obused ôlivad. Igas konkaras õli siis üks obune kõrraga sies. Sai senel kuarm päälä, siis poisikene vai lapsukene vai kes siis vei sene jällä väljälä ja tõine läks siis jällä lauta vai talli siis. Väljäl lahutaja lasi maha. Kiskus kopraga [sõnnikukonksuga] maha ja siis tühü obune tuli jällä laudajuure tagasi. Nõnda siis käidi kõrrast [---].

Sõnnikuvedamise ajast ikka oijeti liha. No siis tehti soust ja kartulid. No võiraasukest kaa kõrjeti senest ajast [selleks ajaks]. A eks see silk õld ikke esimene ja viimane. Kalja siis juadi päälä. Kaera linnassist tehtud kali. Lõune õli supp, ôli siis, mis supp õli, kas siis uasupp, vai ernesupp, vai kartulisupp, a lõune õli ikke supp. Keskõhta võeti naps viina, viedi lauta ja pala leiba päälä. Siis tuaski ei käidud. Õhta õli putru. Tanguputru. Aga kui sõnniku vällä ei saaned, siis putru ei õld. Lõppe putru käis. Siis ôli jällä silgud ja soust ja kartul ja mis kenelgi õli. Ennemast õlivad suured puu lusikad. No peres ôli igaühäl üks, aga siis talgu ajal saadeti lapsed küläst lusikuid tuama. A suured paksud lusikad, siis kartuli korvi sisse siis nied lusikad, siis tuldi, aga puu lusikad korvi sies klõbisesivad. Siis kui keski küläinimine kuuli jua seda klõbina, siis ütläs, et ei tia, kus nied talgud nü̈̈d on, irmus puulusika kolin läks. 
Õhta akketi siis viega luapima üksüht. Tütrikud akkasivad siis poissisid viega kastama siis. Peremes sai kaa ja siis nad ujuned õhta nagu kassi pojad. Siis luabiti üksüht märjäst ja sü̈̈di kõht täis, siis õli tarvis obused kodu viija, siis õli tarvis õitse menna mõnel ja omme jällä kuhugi talgule menna. Siis obuse päälä ja kodu (Jõhvi). (Pajatusi: 96-97)

Maad hariti harkadraga. Enam levinud oli pikkade aiste ja kõrgete käsipuudega ehk kurgedega harkader. Peipsi põhjarannikul ja Narva jõe ääres künti omapärase harkadraga, millel olid lühikesed aisad, madalad käsipuud ja kõver sahkpuu. 19. sajandi keskel hakati kasutama hõlmatru, mis pöörasid mullakamara ümber. Vanemad adrad olid puust kere ja raudhõlmaga, sajandi lõpul hakati kündma juba täiesti rauast adraga. (Moora 1964: 127-135)

Küntud maa äestati äkkega. Vanemateks äkketüüpideks olid kuuselatvja karuäke, hilisemateks pakk- ja raamäke. Kuuselatv-äkkeks oli maharaiutud puu ladvapoolne osa, millele olid külge jäetud tugevamad otsast teritatud

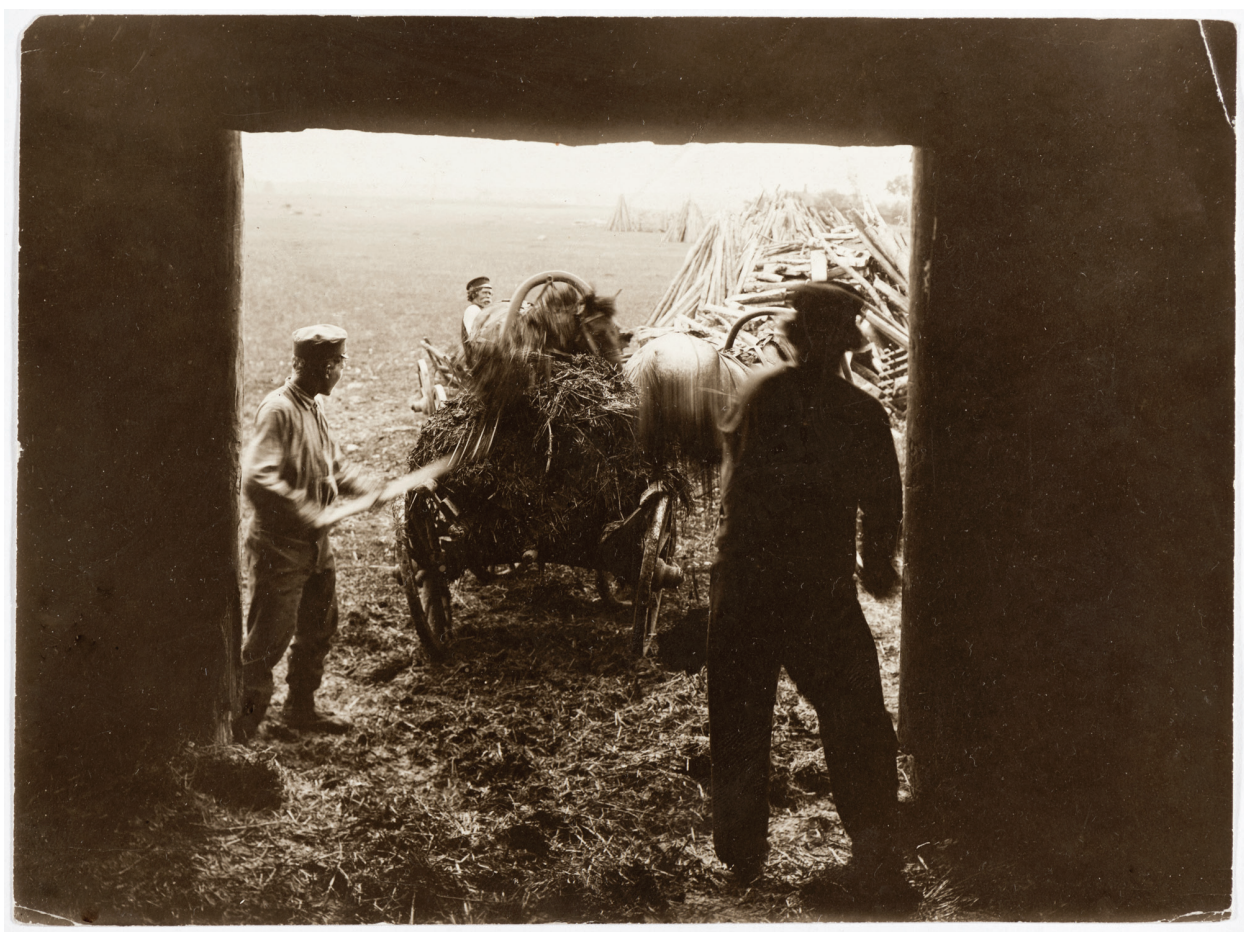

Foto 5. Sõnnikuvedu. Jõhvi khk Pühajõe küla Männelohu talu. J. Pääsukese foto 1913. Fk 214:53. 


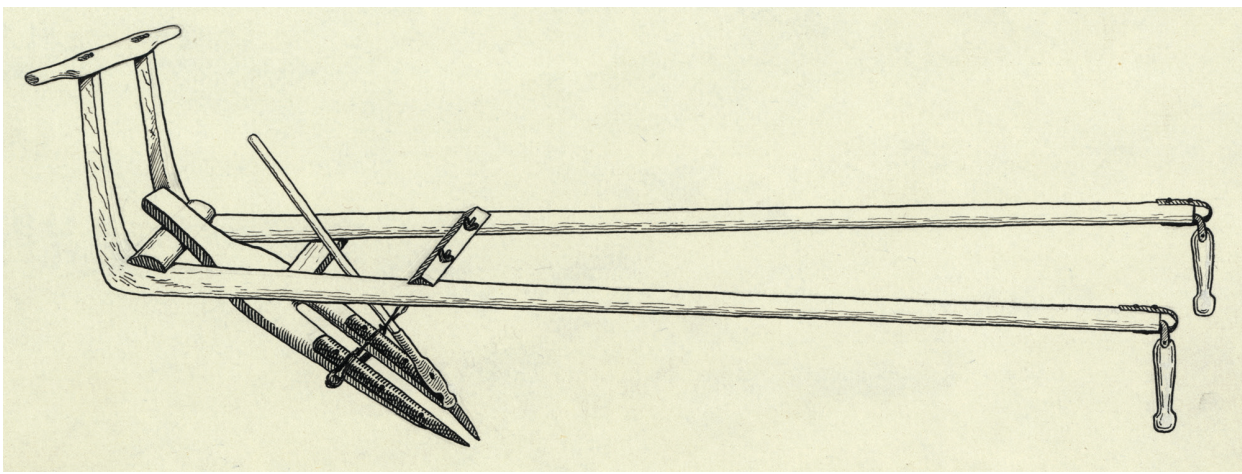

Joonis 5. Kurgedega harkader. Haljala khk Sagadi küla Andrekse talu. V. Pilteri joonis 1957. EJ 179:4.

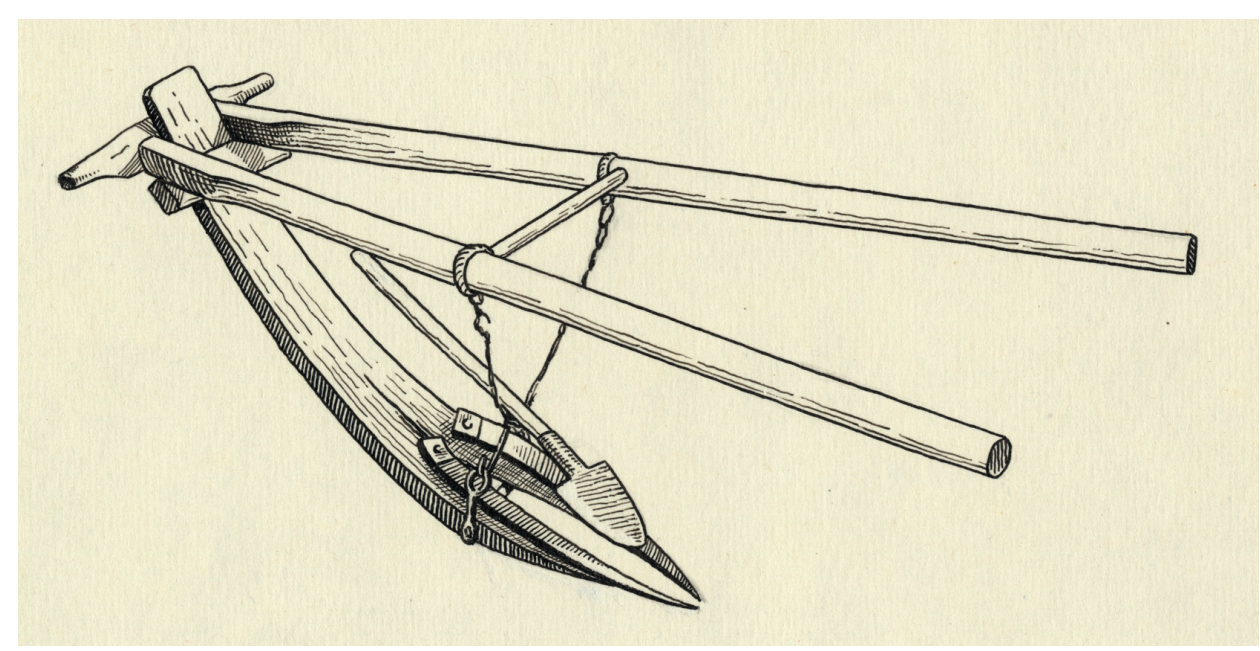

Joonis 6. Kõvera sahkpuuga harkader. Iisaku khk. V. Pilteri joonis 1957. EJ 179:7.

oksatüükad. Karuäke koosnes üksteise kõrvale ritta kinnitatud lõhestatud kuusetüvedest, mil küljes teritatud otstega oksatüükad-äkkepulgad. Pakkäke koosnes kahest või kolmest liikuvast pakureast ja nende sisse löödud pulkadest. Raamäke oli jäiga raamiga, millele kinnitati puust või rauast pulgad. 20. sajandi algul levisid rauast vedru- ja siksak-äke. Viimane muutus mõne aastakümnega valitsevaks äkketüübiks. (Kivisaar-Feoktistova 1959: 11-55)

Vili külvati 20. sajandi alguseni puust külimitust, harvemini külvipõllest. Virumaal olid külimitud ümmarguse põhjaga. Seemendatud vili viidi mulda 
äkkega, mõnel pool adraga. Seepeale rulliti maa põllurulliga. Vilja lõigati sirbiga. Virumaa sirbid olid kitsa hambulise teraga ja lühikese sirge käepidemega. Suvivilja on lõigatud ka vikatiga. (Jaagosild 1978: 51-63) Viljaniidukiga hakati vilja lõikama 20. sajandi algul.

Pärast lõikust seoti rukis vihkudesse ja pandi hakkidesse kuivama. Virumaal oli tavaliselt hakis 10 või 15 vihku. Kui ei olnud võimalik rukist pärast lõikuseperioodi peksta, asetati vihud hakkidest napra. Naber oli kooniline viljakuhil, kus oli mitukümmend või isegi mitusada vihku. (ERKL: 177; Jaagosild 1972) Naprades olid vihud kuni rehepeksuni. Kaera ja otra kuivatati vihkudena hakkides või lahtiselt kärbistel. Need olid lühikeste oksatüügaste või sisselöödud pulkadega tugipuud, mis löödi püsti maasse kas üksikult või ridadena ning nendele laoti vili kuivama. Kaera- ja odravihke on kuivatatud ka piklikus katusekujulises aunas, mis tehti ridamisi püsti üksteise vastu asetatud mitmekümnest vihust ning kaeti pealt küliliasetatud vihkudega. (Jaagosild 1973) Hiljem kuivatati nii rukist kui ka suvivilja veel 1-2 päeva rehetoas parsil, kus rukis kuivas vihkudena, suvivili sasina. Selle aja jooksul köeti reheahju 2-3 korda.

Vilja kuivatamisele järgnes rehepeks. Rukkivihud rabati algul vastu seina või rabamispinki. Üldiselt rabati rehetoas, aga seda tööd on ka rehealuses tehtud. Rabatud vihud võeti sidemest lahti ning asetati rehealuse põrandale, kus neid veel koodiga peksti. Suvivilja ei rabatud, vaid asetati lademena rehealuse põrandale, kus seda on mitmel viisil pekstud. Vilja on tallanud nii inimesed, hobused kui ka härjad, on ka koodiga pekstud. Põhiline suvivilja peksmine toimus hobustega tallamise ehk pahmamisega. 19. sajandi teisel poolel kasutati rehepeksmisel ka reherulli, mille ette rakendati hobune. (Karu 1971; Karu 1975; ERK: 89-92)

Pärast peksmist vili tuulati. Seda tehti sarjaga, mis riputati rehealuse laetala külge, lahtiste väravate kohale. Tuulamiseks võeti algul hõredam, seejärel tihedama põhjaga sari.

...haganatega segatud pekstud terad asetatakse sarja ja soputatakse viimast. Tuulaja seisab tavaliselt pingil, kuna maast ei ulata. Raputamisel terad ühes peenemate haganatega varisevad põhjast läbi. Terad, kui raskemad, kukuvad lähemale maha, kuna haganad kaugemale lendavad. Ülespoole tuult kukkuvad terad on puhtamad, paremad. Mida kaugemale terad kukkunud, seda kergemad ja halvemad nad on. Oige kaugele kukkunud terad on juba tublisti haganatega segatud, nied nimetatakse jätisehunnikuks (Iisaku).

Vili hoiti aidas tünnides, kirstudes ja salvedes.

19. sajandi viimasel veerandil hakati kasutama ka rehepeksumasinaid, mis algul töötasid inim- ja hobujõul, hiljem aurujõul. 


\section{Loomakasvatus ja veovahendid}

Loomadest kasvatati veiseid, hobuseid, lambaid, sigu ja kanu. Veiseid peeti 19. sajandi lõpukümneteni vähe, piima andsid nad napilt. 19. sajandi esimesel poolel künti põldu hobuste ja härgadega, sajandi teisel poolel aga härgade tähtsus vähenes. 20. sajandi algul neid enam põllutöödel ei kasutatud.

Enne talude kruntimist ja päriseksostmist oli karjamaa külakogukonna ühisvaldus ning talude loomi karjatati ühiselt. Karja hoidis küla poolt jüripäevast mihklipäevani palgatud karjane, kellele anti taludest kordamööda abiks laps (karjakorraline). Iga talu andis karjasele loomade arvu järgi tasuks toidumoona ja rõivaid. Sead olid laudas varem ainult talvel, suvel neid karjatati või uitasid nad vabalt väljas. Ka hobused olid suvel ööd ja päevad väljas. Tööhooajal olid nad öösel metsas või heinamaal, neid valvasid õitsilised. (ERKL: 70; ERK: 96-97)

Talviseks loomade toiduks olid heinad, mida heinamaalt vikatiga niideti. 19. sajandi lõpul tulid vikati kõrval kasutusele ka heinaniidukid, aga enne Esimest maailmasõda oli neid talurahval siiski vähe. Kui hein oli kuivanud, pandi see saadudesse. Saadudest tehti heinakuhjad.

Kuhi oli suur ümmargune, ots läks teravaks. Kuhja põhjaks pandi puid, haorisu, latt pandi keskele püsti, toed äärde. Lati ots jäi kuhja päält välja paistma, sellele pandi ümber 3;4;5 vitsa (mõnel pool paaritu arv 3;5) või malka, mis jäid kuhja pääle, et tuul heinu laiali ei kannaks. Lati või varda otsa pandi ümarik soomätas, et vihm varda äärt mööda alla ei tuleks. Kuhjale tehti aed ümber, kus kari ligi pääses. Kui saadu taheti kuhjategemise kohale viia, pandi saadule 2 vitsa või hagu alla ja tõsteti ta reele ning veeti hobusega kohale. Vesisel heinamaal kanti saadud kahe lati peal kuhjategemise kohale. Kuhja suurus oli 1;2;3-5 koormat, mõisas isegi 10 koormat. Kuhjas oli 20 saatu ja rohkem (Viru-Jaagupi).

19. sajandi lõpul, aga eriti 20. sajandi algul hakati suurematesse taludesse muretsema tõuloomi. Kui varem oli hobuste toiduks suvel rohi ja talvel hein, rukki-, odra- ja kaeraõled ning aganad, siis nüüd hakkasid nad rohkem kaeru saama. Levis ristikheina kasvatamine. Kohati karjatati loomi ühiselt. Muretseti koorelahutajad, rohkem hakati valmistama ja müüma võid.

Peamiseks veovahendiks oli talvel regi ja suvel vanker. Hobune rakendati veoki ette aiste, looga ja rangidega. Reed olid 19. sajandi keskpaigani kitsa raami ning puust jalastega.

Ree jalased tehti saarest ehk selle puudumisel kasest. Olid ainult vähe kõverdatud [---]. Pidas regi selle ära ja oli muidu veel kõva, pandi teised mõned pidasid kolmed tallad läbi. Tallad olid jalase laiused ja 3-4 tolli paksused (Viru-Jaagupi). 


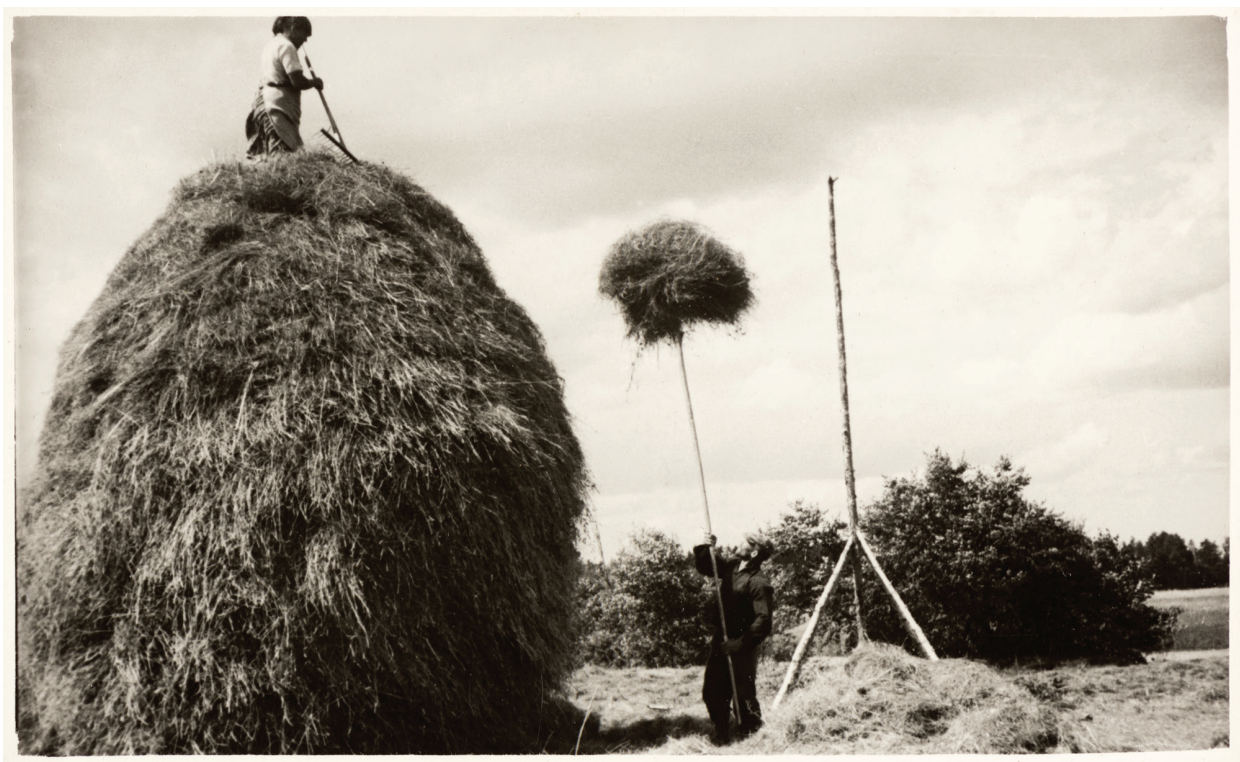

Foto 6. Heinakuhja tegemine. Iisaku khk Rannapungerja küla Kelu talu.

F. Linnuse foto 1936. Fk 771:3.

19. sajandi teisel poolel levisid laia raamiga reed, jalaseid hakati rautama. Virumaal oli Ida-Euroopa regi ehk sebaregi. Sellel oli reepea kõrgele üles painutatud.

Suvine veovahend oli nelja rattaga vanker. Rattad olid varem ilma raudvitsteta. Kuigi neid rautati vitstega juba 19. sajandi esimesel poolel, levisid rautatud rattad laiemalt sajandi teisel poolel. Sõiduks kasutati kahe rattaga kaarikuid, sajandi lõpul ka vedruvankreid.

\section{Kalapüük}

Kalapüügiga tegeldi Peipsi ja Viru rannikul, vähemal määral jõgedel; suurim tähtsus oli Narva jõel, kus väärtuslikumaks kalaks oli lõhe. Peipsi põhjarannikul on püütud rääbist, siiga, latikat, ahvenat, haugi, tinti, kiiska, koha, lutsu, linaskit jm. Kala püüti Peipsist ahingute, õngede, võrkude, nootade, vitsmõrdade ja rüsadega. Nii Peipsi järvele kui ka jõgedele tehti varbadest või võrkudest kalatõkked, millega suleti kalade liikumine ning juhiti need tõketesse jäetud avade kaudu mõrdadesse. Ahinguga on kala püütud madalas vees nii järvedes, jõgedes kui ka meres, sellega on kalal käidud nii päeval kui ka öösel, mil vett valgustati lõkkega. Tuli tehti laudadest lavatsile asetatud mätastele või seati paadi nina külge kinnitatud toosehargile. (ERK: 107-122) 
Viru ranniku püügikalaks on olnud räim, kilu, koha, ahven, siig jt. Kalu püüti võrkude, nootade ja rüsadega. Püünised valmistati linasest niidist. 19. sajandi viimastel aastakümnetel on neid hakatud tegema ostetud puuvillasest niidist. Tähtis kalapüügiriist oli noot. See oli järelveetav võrgust kalapüügiriist, koosnes ühest või kahest tiivast, kotikujulisest tihedast pärast ja pikkadest veoköitest. Püügil ümbritseti kalaparv noodaga, seejärel tõmmati see kaldale või paati. Virumaa rannikul juhtis kalapüüki kallaspapp, kes paekaldal räimeparvede liikumist meres ja loodusmärke (kajakate lend, vee värv) jälgides andis kaluritele märku nooda vettelaskmise ja tõmbamise kohta. Nii põhjarannikul kui Peipsil on noodaga kalu püütud ka talvel jää alt. Haljala ja Viru-Nigula randlased on sajandeid käinud rändpüügil Soome lahe saarte (Tütarsaar, Länsiviiri, Suursaar, Kilpisaari) ümbruses. (Luts 1960; Moora 1964: 165-222; ERK: 107-122)

Eestis käisid rändpüügil Loode-Venemaa kutselised kalurid, kõige rohkem oli neid Tveri kubermangu Ostaškovi maakonnast. Nii põhjaranniku kui Peipsiäärsed kalurid ostsid venelastelt või valmistasid nende kalapüügivahendite järgi uusi kalapüüniseid, nagu suur süvaveenoot ja väike noot - mutt. Muti külge kinnitati 200-300 meetri pikkused köied, mille külge seoti võrguräbalaid ja õletuuste. Kalapüügil ajasid muti köied üles põhjamuda, sogane vesi takistas kalu loomuse piirkonnast põgenemast. (ERKL: 171)

Walter Jõgi (KV 417) on kirjeldanud Peipsi põhjaranniku kalurite riietust 19. ja 20 sajandi vahetusel:

Peipsi kalurid kandsid suvel ja talvel linaseriidest aluspesu: särki ja aluspükse ja täisvillasest riidest kuube ja pealispükse. Talvel kanti ülakeha soendamiseks villasest lõngast kootud kampsuni või lamba karusnahast vesti. Üleriidena kanti lamba karusnahast kasukat ja pealisriidena villasest riidest pikka kõrge kraega ülikuube. Kasuka hõlmad nööbiti kinni nööpidega, ülikuub seoti keskelt kinni villasest lõngast punutud vööga. Üksikud kalurid kandsid talvel lamba karusnahkseid pükse. Kalurid kandsid suvel ja talvel säärega saapaid. Labajala soendamiseks kanti villaseid sokke ja sukke, mis alati kaeti linasest riidest jalanartsudega, tallukatega. Iga kalur, kellel oli tegemist märja võrguga, märja püüniste nööriga või köiega, kandis nahast pikka rinnapõlle, mille alumine äär ulatus allapoole säärsaabaste sääre ülaäärt. Käes kanti alati pealiskindana nahkseid labakindaid. Kõiki nahkseid säärsaapaid, kindaid, põllesid määriti-võieti kasetohu tökatiga. Tökat hoidis pargitud naha pehme ja veekindla. Vilte kalapüügil ei kantud. Kummikuid toona ei tuntud. 


\section{Küttimine}

Talurahva elus oli küttimine vähetähtis. Jahti piirasid mitmesugused keelud, see oli aadlike eesõigus. Küttimisega on rohkem tegeldud Alutaguse metsades ja suuremalt osalt oli tegu salaküttimisega.

Vanasti kuulusid metsad mõisnikkudele ja ühes metsadega ka metsloomad. Talupoegadel küttimiseks õigust ei olnud, kuid ta võis põldude kaitseks abinõusid tarvitusele võtta ja kiskjaid loomi hävitada. Arenes salaküttimine, mis oli valjult karistatav. Et metsloome ja linde metsades küllalt oli, siis polnud kerge, eriti metsade ja rabaäärseis kaugeis taludes keelumä̈̈ruseid maksma panna [---]. Salakütid olid osavad ja kavalad mehed (Iisaku).

Kütitud on põtru, metskitsi, jäneseid ja karusloomi: rebaseid, ilveseid, saarmaid, nugiseid ja oravaid; lindudest laanepüüsid, nurmkanu, tetri, metsiseid, parte ning hanesid. Jahti peeti püüniste ja püssiga. Püüniseid oli mitmesuguseid: augud, kast- ja lööklõksud. Augud kaevati loomade rajale, kaeti okste ja samblaga, millele pandi sööt. Põdraauk oli kuni kolme meetri sügavune. Talvel püüti jäneseid lumme kaevatud aukudega, mis kergelt õlgedega kaeti, peale asetati ristikheinu. Kastlõksuga kütiti rebaseid, tuhkruid ja nugiseid. Nakas oli aga selline lõks, kus palk oli seatud nii, et see sööta haaravale loomale peale langes (püüti saarmaid, jäneseid ja linde). Raudadega kütiti kõige enam rebaseid, aga ka saarmaid ja ilveseid. Kui loom astus raudade keskel asuvale plaadile, paiskusid rauad vedru jõul kokku, loom jäi jalgupidi nende vahele. Püsse oli talurahval vähe, need olid 19. sajandil eestlaetavad. Padrunitega laetavaid püsse hakkas talupoeg kasutama 20. sajandi algul. (Loorits 2004: 350-357; ERK: 125-126)

Lindude pü̈̈dmiseks asetati metsa kavalalt ehitatud silmused. Silmuseid tehti palju ja neid asetati mitmele poole, nii et nende abil läks korda lindu tabada. Silmus koosnes vibust, mille ots tugevasti maa sisse oli kinnitatud; vibu ülemise otsa küljes oli nöörist silmus. Vibu painutati looka ja kinnitati orrna pulga abil looga külge, mis maa külge kinnitatud. Vibu ülemist otsa kinnihoidva ristpulgakese peale olid ornalt asetatud pulgad, mille peale õrnalt silmus asetati. Silmuse ühele ja teisele poole asetati marjakobar. Kui lind ühe marjakobara tühjaks sõi, hüppas ta ristvarvale, mis sidepulga linnu raskuse mõjul järsku lahti päästis ja vibu püsti kargas, lindu jalga- ehk peadpidi silmusesse tõmmates. Mida rohkem lind silmuses rabeles, seda tugevamalt ta silmuse kinni vedas (Iisaku). 
Tetrede küttimise abivahenditena kasutati tedrekujusid.

Tedrekujud tehti riidest, mille juures tedrekujule täiesti tedre välimus anti. Kuju täideti seest sambla, taku ehk saepuruga, pealt värviti üle ja kinnitati suled külge. Kujusid oli igal kütil 3-5 tükki. Kujud kinnitati tugevasti nööriga pika varva külge ja asetati nad varvaga kaselatva. Eemalt paistsid kujud täiesti tedresarnastena. Seda petust ei aimanud tedred ja lendasid kujude juurde. Teder on väga ettevaatlik lind ja iga kahtluse juures lendab ta kaugele. Kui ta aga kujusid puus nägi üsna rahulikult istuvat, jõudis ta veendumusele, et ümbruses midagi karta ei ole. Et kujude läheduses valvata ja juurdelennanud tetri lasta, ehitas kütt okstest kaitsevarju, mille tagant ta kujude juure lennanud tetri laskis (Iisaku).

Hundid olid 18. ja 19. sajandil tõeliseks nuhtluseks, nad murdsid koduloomi ja tungisid kallale inimestelegi. Mõisad korraldasid ajujahte, millest võttis osa sadu talupoegi ja mõisajäägreid. Hundid piirati ümber ja aeti suurt kära tehes püünistesse või küttide ette. Mõnel pool seoti huntide sissepiiramiseks puude külge lipukestega nöörid. Talupojad pidasid püssiga huntidele hiilimis-, peibutus- ja varitsusjahti, aga hunte kütiti ka hundiaedade, -aukude, -raudade ja -õngedega. (ERK: 125)

Hiilimisjahil hiilis kütt päeval magavatele huntidele laskekaugusele ning tulistas neid. Hunte peibutati seapõrsa või kutsikaga.

Et hundid talvel näljased olid ja tihti tee ääres luusisid, korraldasid mehed järgmisel viisil hundijahi. Nad istusid 2-5-kesi rekke ja sidusid pika nööri otsas heinakoti ree taga järele jooksma. Et hunti juure meelitada, võeti tavaliselt põrsas ehk kutsikas kaasa. Muist mehi hoidsid püssid laskevalmis, üks hoolitses selle eest, et põrsas või kutsikas hästi pidi kisama. Hundid, kes kisa kuulsid, ruttasid teele, kus nad rege ja selle järel hüplevat kotti nägid. Teel "kikerdavat” kotti koeraks pidades viskusid nad aplalt selle kallale. Seda ootasidki kütid. Et hundid laskekaugusesse olid tulnud, anti reest tabavat tuld (Iisaku).

Hunte on püütud ka hundiaedadega, mis olid ringidena ehitatud umbes kolme meetri kõrgustest teivastest. Taral oli kaks, harvemini kolm ringi, mille sisse pandi lammas või kits. Kui hunt välistara väravast sisse tuli ja siis edasi liikus, sulges ta sissepoole avanenud värava oma kehaga ega pääsenud püünisest välja. (Loorits 2004: 352-353) 


\section{Talurahvakaubandus}

Sajandeid on talurahvas müünud oma tooteid linnades ning vahetanud või ostnud sealt vajalikku kaupa. Linnades olid turud, kus talupojad müüsid ja talurahvapoed, kust nad ostsid kaupu. Tähtis osa talurahvakaubanduses oli laatadel. "Sirvilauad. Eesti Rahva Tähtraamat 1913" toob ära Eestis toimuvate laatade ajad ja kohad. Narva linn kuulus sel ajal administratiivselt Peterburi kubermangu, aga tähtraamatus on toodud ka Narva laadad. Vaatleme Virumaa laatasid 1913. aastal.

Näärikuus (29. ja 30.) oli laat Rakveres; küünlakuus (6. ja 7.) Narvas, (18. ja 19.) Jõhvis, (23. ja 24.) Iisakus ja (24. ja 25.) Kulinal (Viru-Jaagupi); paastukuus (8. ja 9.) Laekveres (Simuna), (10.) Vasknarvas (Vaivara) ja (26. ja 27.) Vaivaras; jürikuus (15. ja 16.) Rakveres, (17.) Palmses (Kadrina) ja (26.-28.) Narvas; jaanikuus (16. ja 17.) Rakveres, (20. ja 21.) Palmses ja (20.-22.) Viitnas (Kadrina); mihklikuus (1. ja 2.) Iisakus, (20.-22.) Narvas ja (20.-22.) Palmses; viinakuus (2.-4.) Rakveres, (4.-6.) Jõhvis, (7. ja 8.) Laekveres ja (19. ja 20.) Kulinal; talvekuus (26.) Kulinal; jõulukuus (1.) Vasknarvas, (2.) Rakveres ja (9.) Narvas.

Laatadel turustas oma kaupu nii maa- kui ka linnarahvas, seal müüdi hobuseid, veiseid, lambaid, sigu, vankreid, regesid, atru, vikateid, sirpe, linu, villa, nahku, rõivaid, kangaid, jalatseid, naiste- ja meeste käsitöid, raamatuid, toiduaineid, maiustusi ja palju muid kaupu. (EA V: 180-181) Taluteenijatele anti tavaliselt üks vaba päev aastas laadal käimiseks.

Põhiliselt käisid laadal ümbruskonna inimesed, aga ostmas ja müümas käidi ka kaugematel laatadel. Nii müüsid potisetud savinõusid, Avinurme mehed puuesemeid ja Tudulinna vokimeistrid oma toodangut paljudel laatadel. Vokimeister Ludvig Suurväli jutustas:

Mü̈̈gil käimine algas sügisel Laekvere, Rakvere ja Jõhvi laatadega pihta. Esimesteks käijateks olid alates septembrist väikekrundimehed, neil põlluga vähem tegemist. 20. septembril oli Narva laat, seal käisin pea iga sügise ära. Oktoobris-novembris läks käimine suuremaks [---]. Tegijaid oli palju, üks läks oma koormaga ühele poole, teine teisele, kolmas kolmandale poole. Mina käisin Tallinna pool Jõelähtmeni, üks või kaks meest käisid vahest ka taha Tallinna. Harva käisid, oli juba väga kauge käia. Tartu poole sai korra Võrtsjärve ääres ära käidud, aga sinna palju ei käidud, sääl olid jälle oma tegijad [---]. Peale jõule sai vokke rohkem Venemaale viia. Hind oli pea üks igal pool, nii Eestis kui Venes (Iisaku).

Laadal oli ka lõbustusi, esinesid torupilli- ja lõõtspillimängijad, mustkunstnikud, karutantsitajad, palaganitegijad, seal oli tsirkus ja karussell. Suurematel laatadel oli rohkem, väiksematel vähem lõbustusi. (ERK: 189-195) 
Kalamehed vahetasid kala ülejäägid vilja vastu. Virumaa siseküladest käidi Peipsiveerel ja põhjarannikul kala toomas, kalamehed sõitsid ka ise mööda külasid kala vilja vastu vahetama. Viru rannikul on silkudega kaubelnud ka Soome kalamehed Suursaarelt, Tammiolt, Haapasaarelt, Tütarsaarelt ja mujalt. See oli vana sajandeid kestnud sõbrakaubandus soomlaste ja eestlaste vahel. (ERK: 184-186)

Mööda külasid liikusid ringi harjuskid, kes olid valdavalt venelased. Vanemal ajal käisid nad jalgsi, hiljem hobustega. Harjuskid müüsid niiti, nõelu, riidevärve, linte ja mitmesuguseid kangaid.

Tuadi särgiriideid ja püksiriideid ja pluusariideid ja kleidiriideid, põlleriideid ja naiste piarättikuid. Igat seltsi ôli neid riideid (Jõhvi).

Sügise ja talvel tulivad Avinurmest riistategijad küläde riistu mü̈̈mä. Sügise tulivad kapsa tõrsi perenaistele tuama. Kõige rohkem käidi lume tiega. Rie päälä õli tehtud põigite lattidest kõrge korv, et riistad maha ei kukku. Sääl kuarmas siis õlivad võikarbid ja silgukarbid, lähkrid ja leivaastjad ja audumisetõrred ja lihaastjad, kapsatõrred, pesukünäd, vasika kappad, lüpsikud, kirnud, kibud, vitsikud, putru männäd, putru nuijad, puu kulbid ja mis sääl kõik õlid, nindat kõiki puu riistu, mis küläs ikke vaja ôli. Neid müüdi rahaiest ja vahesteti viljaga, kuda kaupa saadi. Siis kes tahi omale tellida miski asja, siis kui tõinekõrd tuli, siis tõi kodu, tellitud tü̈̈ pidi ikke pali paremb õlema (Jõhvi). (Pajatusi: 207)

Potisetud vahetasid savinõusid kaltsude vastu, kuid ringi liikusid veel ka kaubajuudid, kes pakkusid plekknõusid, aga ka põrsa-, sibula-, tökati-, seemne- ja raamatukaupmehed. Külapoode oli kuni 19. sajandi neljanda veerandini vähe, aga sajandi viimastel aastakümnetel nende arv kasvas ning enne Esimest maailmasõda oli maal juba üsna palju poode.

\section{Toit}

Talurahva tähtsamaks toiduks oli rukkileib. 19. sajandi keskpaigani on rukkijahusse puistatud peenestatud aganaid, tainas segati ja hapendati leivakünas. Sajandi viimasel veerandil tulid kasutusele laudadest kolme jalaga leivaastjad.

No kui nü̈̈d leiba tegema akketi, siis tuadi pualvakkatäis jahu ja pandi sinne astja ja valati ia suur ämbritäis leiget vett päälä. Siis no siudeti (segati) kääga segamine, siis pandi astja riijestega kinni ja lükkäti vastu suaja ahju appanemma. Kui ühä üäga appust ei saand, siis piati (peeti) 
kaks, aga suurembosa sai ühe üäga kerkind. Kui kerkus [kerkima pandud taigen] ôli kerkind üläs, siis ei ôld appu, a kui ôli käind üläväl ja langend alle tagasi, siis ôlivad appud. Siis tuadi üks kõvemb puolvakk jahu ja sõtkuti vällä [ära]. Sõtkumine pidi õlema kõva, siis leib pidas kauemb vasta. Sõtkuti kahe kääga, kääd õlivad rusikas. Pera sõtkumist tehti taigen siledast ja pressiti sõrme augud risti sisse, et siis saab aru, kas on kerkined. No siis küäti ahi ägädast [kuumaks] ja siis rippudeti lauale jahu ja jagati siis astjast kas siis kuus vai neli leiba ja siis pera kaabiti viel asti puhtast ja tehti siis kaapekakk. Siis nied taignapätsid pandi lauale ja vaaliti vällä ja, ja jääti lauale kerkima nindakauast, kui tõmmeti sü̈̈d ja luuditi ahi.

No sie luudimine käis ninda, et ôli üks vana pütt ja sääl õli vesi sies ja siis sie luud kasseti sinne vette ja siis pühüti ahjust tuhk vällä. Süäd jääti liede. No siis pandi leivad labida päälä ja pandi ahju.

No ennevanast kella ei õld, aga sääl nad tiasivad, milla leivad ahjust vällä võeti. Nindat kaks tundi oijeti leivad ahjus. Leiva aisust ka saivad aru, milla on küps. Ja kui selge päiv ôli, siis arvati päiväst. Vahetevahel, siis kui sie aig jua arvati õlema, võeti leib ahjust vällä ja koppudeti sõrmega alle ja kui ei õld küps, pandi tagasi. Kui leib õli küps, siis ei tõhtind enamb suitseda, aga taignane leib suitses. No kui nüüd õlivad leivad küpsäd, siis võeti ahjust vällä ja pandi üks vana riide päälä (Jõhvi). (Pajatusi: 103-104)

Talupere igapäevased toidud olid pudrud, kördid ja leemed (supid). Puder keedeti odra- või rukkijahust või tangudest, kört (vedel puder) odrajahust. Tangupudrule on lisatud piima, rasva või pekitükke, kördile piima. Leent on keedetud odratangudest, hernestest, ubadest, kapsastest, kartulitest, kalast ja lihast ning vastavalt maitsele ja võimalustele on neid seguna valmistatud ja juurde lisatud kas naereid, kaalikaid, piima, rasva jm. Kaerajahust valmistati kiislit ja kaerakama. (Moora 1980: 146-150) Kiisli tegemisel

...kaerajahu pannakse leigesse vette ning lastakse üks öö soojas kohas seista, kus ta hapuks läheb. Kiislil on harilikult oma astja, mida kunagi täielikult puhtaks ei pesta, selletõttu jahu hapneb seal kiiremini. Järgmisel päeval keedetakse hapnenud jahud pudruks. Pudru on hästi libe, kibekas-hapuka maitsega. Süüakse kas võiga ("või silmas”) või rõõsa piimaga niihästi soojalt kui külmalt (Iisaku).

Varematel aegadel söödi naereid, kaalikaid ja kapsaid, 19. sajandi teisel veerandil hakati rohkem kartulit tarvitama. Sajandi lõpus oli kartul üldine, naeris taandus. Piima oli taludes vähe, lehmad olid väikese piimaanniga. Seoses karjamajanduse arenguga sajandi viimasel veerandil suurenes ka piima tarvitamine. 
Kaladest söödi enam soolasilku. (Moora 1991: 211) Eriti headeks peeti soomlaste silke:

Meie rahvas aina kiitis, et kui hästi on Suursaare silgud soolatud. Sõime neid toorelt, küpsetatult vardas, keedetult ja praetult. Vanaema toimis nendega mõnikord ka nõnda: kui keedetud kartulitelt vesi ära kallatud, laoti rutuga silgud kartulitele ritta ja pandi pajale kaas peale. Kuumas aurus olid silgud varsti pehmed (Haljala).

Mere, jõgede ja järvede ääres söödi ka teisi kalu. Rohkesti sõid kalu Viru ranniku ja Peipsiäärsed elanikud. Liha söödi 19. sajandil suhteliselt vähe, sügisest kevadeni 1-2 korda nädalas, peamiselt soolatud sea-, veise- ja lambaliha. Alutagusel saadi lisa metsloomade küttimisel. (Moora 1991: 187-244)

Talupere tavaliseks joogiks oli kali, pidupuhkudel õlu. (Moora 1991: 91-99) Kevadel joodi ka mahla:

Ennemast õli mahl lastel suur asi. Ja vanudel ka. Käisivad mitme virsta tagand einamitelt kaskidest ja vahtradest mahla tuomas. Vahtral õli magusamb mahl kui kasel. Uuristeti uherdiga kaske auk sisse ja siis puu tila siis sinna auku. Õli üks puu lõhestetud ja uuristetud künämuadi ja õts õli siis sääl aukus ja pütt õli all, kuhu siis juaksi. Iga ommiku siis käidi siis tuamas, siis päivä ja üä tilkus. Sie õli vanarahva arstirohi ka, kohvi tehti ka mahla sies, siis ei ôld suhkurt tarvis, mahl ôli magus (Jõhvi). (Pajatusi: 114)

19. sajandi lõpul hakati jooma kohvi, peamiselt siguri- ja viljakohvi. Põhjarannikul joodi vähesel määral Soomest toodud oakohvi. Levisid linnapäritoluga toidud: riisi- ja mannasupp, praeliha, pannkoogid, kompotid jm.

Vaatame põgusalt 19. sajandi tavanditoite Virumaal. Surnu valvajatele pakuti soolaga keedetud herneid. Tanguputru söödi katsikul, pulmas, surnu valvamisel ja ärasaatmisel. Tanguvorst oli laual pulmas ja jõulude ajal. Alutagusel varem verivorsti ei valmistatud, alles 19. sajandi lõpul hakati seda tegema, Lääne-Virumaal on seda ka varem tehtud. (Moora 1991: 269-272)

Ennevanast ôlivad valged vorstid, veri ôli ing, seda süijä ei tõhtind. Niisikene trehter õli ja pulk ja pisikesed pulgad, miiga vorsti õtsad kinni pandi. Tangud keideti pehmest, mitte nii pehmest kui putrule, ja siis pandi sibulaid ulka ja maa müntisid lõigeti ka ulka nattukese ja siis jahudeti putru külmäst, et käsi ei põleta ja suale õts pandi pulgaga kinni ja tõine otts trehtri külgä. Enne viel puhuti suolest õhku läbi. Putru tõsseti kulbiga trehtri ja tauti pulgaga suale (soolde) ja pera siis pandi sie tõine õts ka sinne pulga külgä, mis all õtsas õli, kui vorst täis sai. Siis vorst jäi niisikene ümmärgune. Pühädä laupa üäldi lastele, et kui esimesel pühäl külä lähäta, 
siis pannakse sie rasvane vorst kaela. No kes tõhtis menna. Saivad vorstid valmis, siis pandi pada ja keideti siis sual ka pehmest ja siis tangud $k a$ viel pehmemast. Sie ôli siis kuppastamine. Siis lauditi vorstid laudade päälä, et kui suajalt jääväd unniku, siis lähväd usina appust ja siis nüüd minu emaema ajal ikke õli jua pannid, siis ükskõrd aastas jõululaupa sie vorstitegemine õli, siis pandi pannidega ahju (Jõhvi). (Pajatusi: 112-113)

Vastlapäeval olid seajalad ubade ja hernestega, mardipäeval söödi kukk või kana. Tõnisepäevaks ja jõuludeks on keedetud seapea koos kapsastega.

Vanal ajal, kui mina nü̈̈d kuulin, siis kanamuni nägivad ainult pühädä ajal. Lihavõtte ja nelibüpühädä ajal. Kõrjeti siis igä̈̈hälä siis kuda õli, kas kaks muna ehk kolm ehk, siis pandi pühädä laupa vana sauna viht pada ja munad ka sisse ja jagati siis pere vahel vällä. Ja siis õligi see munasaak. Kui taheti viel pruuni muni, siis pandi sibula kuaridega kiema. Ja siis keideti viel munidest munaruaga, aga sie õli ka siis pühädä aig, vai pühäpäivite, aga arvast siis juhtus niisikest asja. Keideti piim paas üläs, lasti kiema menna ja no võeti siis sääl üks puole kausi jagu appupiima, lüädi üks viis muna siis sinne sisse, kloppiti iast segamine, lasti siis pada, piima sisse. No siis liigutati iast segamine, nindat jäi siis munaruag. Siis lasti menna uuesta kiema ja sie oli munarua supp (Jõhvi). (Pajatusi: 110-111)

Varrutoiduks oli munaroog ja klimbisupp, pulma viimaseks toiduks kapsasupp, mõnel pool ka klimbisupp. Pidulikeks sündmusteks pruuliti õlut odralinnastest, vahel ka rukkilinnastest.

\section{Rahvarõivad}

Virumaa rahvariided kuuluvad Põhja-Eesti rahvarõiva rühma. Ainult Iisaku poluvertsikutel olid need teistest täiesti erinevad. 19. sajandi naise rõivasteks olid särk, käised, seelik, vöö, kohati kampsun ja liistik, abielunaisel ka põll ja tanu. (Kaarma \& Voolmaa 1981)

Särk oli ilma varrukateta. See oli kokku õmmeldud linasest pihast ja takusest alasest. Särgi peal kanti napilt rindade alla ulatuva kahara pihaosa ning laiade varrukatega linasest riidest käiseid. Töökäised olid lihtsad või päris ilma kaunistuseta. Pidulikud käised kaunistati rikkalikult lillkirjas tikandivööndiga. Kirjaks oli väät lopsakate õite, viljade ja pungadega. Õie motiiviks oli sagedamini kelluke, esinesid ka roos, nelk jt. Alläär pilutati või õmmeldi sinna niplispits. Pidulike käiste piht kurrutati kuni tikandini. (Voolmaa 1962: 215-221, 227-228; Voolmaa 2013) 


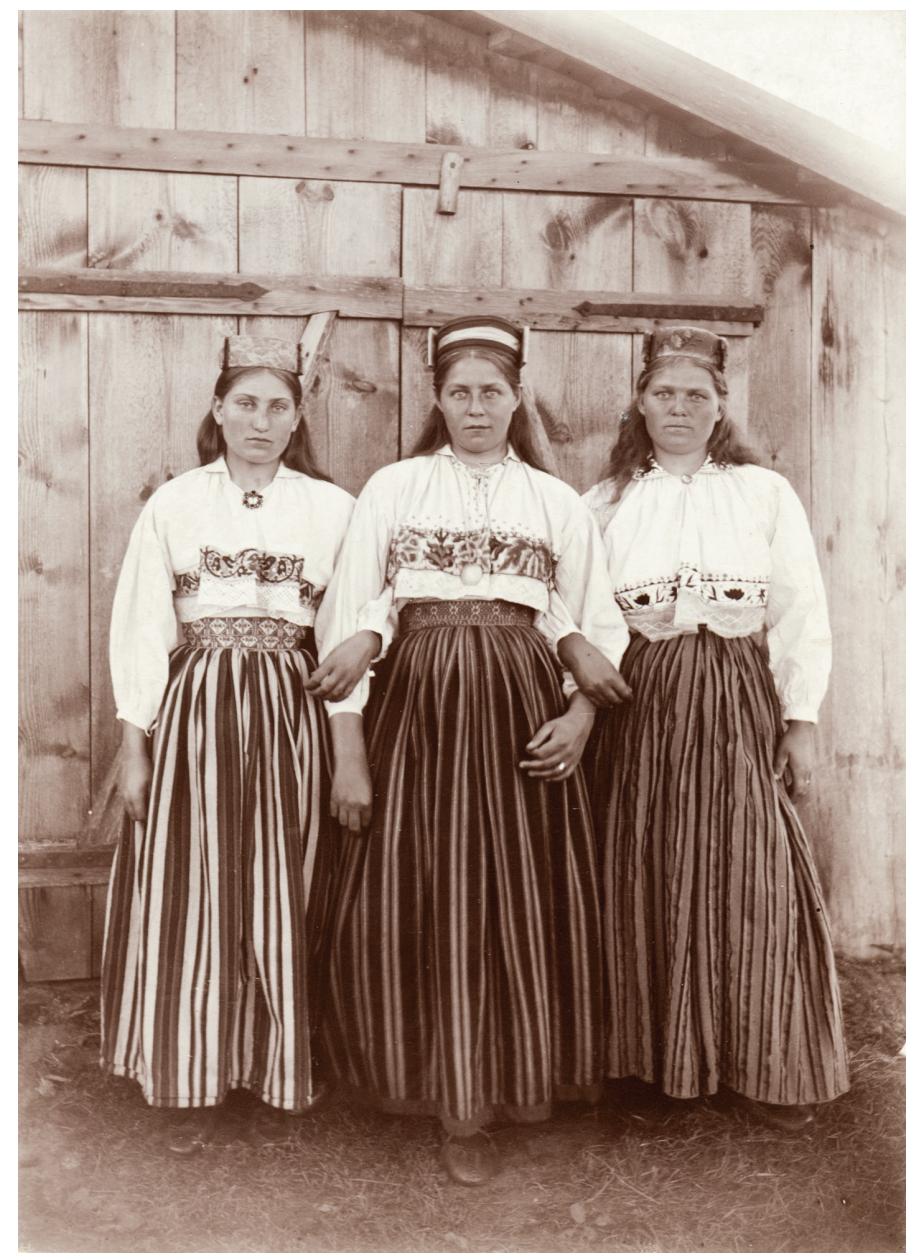

Foto 7. Kolm neidu. 20. sajandi algus. Kadrina khk. Fk 182:8.

Seelikuks oli 18. sajandil kas must ümber puusade mähitud riidelaid või kokkuõmmeldud ümbrik, mille alläärt kaunistati sinise või punase äärepaelaga, aga ka kardpaelaga. Alutaguse ümbrikule oli iseloomulik punasele villasele riidele värviliste helmestega tikitud lai alläär. 18. sajandi lõpus oli see tikand valdavalt lillkirjaline. 18. sajandi esimesel poolel levisid Põhja-Eestis osturiidest kaharad, värvli juurest tihedalt volditud seelikud. 18. sajandi lõpul ja 19. sajandi algul peeti Alutagusel lugu rohelistest seelikutest. 18. sajandi keskpaiku tulid Põhja-Eestis kasutusele esimesed mitmevärvilised pikitriipudega seelikud, mis 19. sajandi esimesel poolel said peorõivastena üldiseks. Virumaa seeliku 
triibustikus esines rohkesti rohelist värvi. Jõhvis on meelisvärviks olnud punane. Samaaegselt pikitriibulise seelikuga olid rohkem töörõivana kasutusel ühevärvilised seelikud. (Voolmaa 2013)

Vööga mähiti mitmekordselt seeliku (abielunaisel ka põlle) värvel ning sellest kõrgemal olev käiste ääre alt vabaks jääv vöökoht. Vöödele oli valgele linasele põhjale värvilise villase lõngaga korjatud geomeetriline kiri. Sarnaselt seelikutega esines ka vöödel sagedasti rohelisi toone. (Voolmaa 1962: 223-224; Voolmaa 2013)

Põlle kandsid abielunaised. Noorikutele pandi põll ette pulmas linutamisel koos peakattega. 18. sajandil ja 19. sajandi algul on hinnatud rohelisi poevillaseid kard- ja värviliste (enamasti punaste) paeltega kaunistatud põllesid. 19. sajandi esimesel poolel kanti rohkesti kirjust sitsist või õhukesest valgest puuvillasest nn klaarriidest põllesid. Tihti olid põlled pikitriibulise mustriga, esines ka ühevärvilisi helerohelisi, lillasid ja siniseid põllesid. 19. sajandi teisest poolest on andmeid põikitriibulise alasega põlledest, kantud on ka valgeid pitsäärisega põllesid. Kampsunit kanti Virumaal ainult Väike-Maarja, ViruJaagupi ja Simuna kihelkonnas.

Õlakatetest on 19. sajandi esimesel poolel kantud sõba, aga sajandi keskpaigas sai üldiseks suurrätik. Neiud käisid palja peaga või kandsid pärga - riidega kaetud laastust või papist võru, mis kaunistati paelte, litrite ja helmestega. Abielunaiste peakatteks olid pealinik ja mitmesugused tanud: linuk, harjakas, teravatipuline tanu. Neid kaunistati lillkirjaga, mis oli käisekirjaga sarnane (Kreutzwald 2012). 19. sajandi esimesel veerandil hakati kandma pottmütse, mis sajandi keskel olid üldised. Tööl kandsid nii naised kui neiud peamiselt rätikuid, mille otsad tavaliselt seoti lõua all sõlme. (Voolmaa 2013)

Tavaliseks kaelaehteks olid naistel klaashelmed. Jõukamad kandsid pidulikel juhtudel hõbekette koos kannaga rahadega. Igapäevaseks ehteks oli vitssõlg, pidulike rõivastega ehiti rinda sakiliste servadega preeside ning kuhiksõlgedega.

Meeste rõivastus koosnes 19. sajandi esimesel poolel särgist, põlvpükstest ja vatist, kohati ka vestist. Särk oli valgest linasest riidest, suvepüksid linasest või takusest, talvepüksid villasest riidest. Rikkad kandsid nahkpükse. Pükste sääred ulatusid väheke allapoole põlvi. Vatti nimetati kampsuniks ning see ulatus poole puusani. Neid valmistati nii sinisest villasest kui ka linasest valgest riidest. Vesti kanti peamiselt piduliku ülikonnaga. Peakatteks oli suvel vildist kaapkübar, kanti ka muru- ja tuttmütse. Talvel oli meestel peas lambanahkne lontmüts. Ülerõivana kandsid nii mehed kui ka naised villaseid pikk-kuubi ja lambanahkseid kasukaid. (Voolmaa 2013)

Tavalisteks jalanõudeks olid nii meestel kui ka naistel pastlad, tehti ka puukooreribadest (kask, pärn, paju) viiske. Nende kõrval olid põhjarannikul 
kasutusel veel soome sussid: naistel madalamad susskingad, meestel peaaegu põlveni ulatuvad suss-saapad. Naiste susskingi

...pidi iga mees ise oskama oma naisele teha. Susskingi kanti igal pool, nii kodus toas, teed käies ja rannal vastel [vastas] käies. Ühesõnaga üks asendamatu jalanõu, mida kanti nii suvel kui talvel (Haljala).

Meeste suss-saabaste

...tegemiseks oli juba meistrit vaja, sest sussid pidid hästi vett pidama. Paati merde lükates tuli niikaua vees olla kuni paat ujuma hakkas ja alles siis sai paati hüpata [---]. Sussi tuli hästi hooldada ja määrida küll hülge-, searasva, tõrva ja tökatiga, et nad vett läbi ei laseks ja kauem vastu peaks. Susside põhja pandi veel õlgi, siis oli soojem (Haljala).

Vanemate jalakatete hulka kuulusid nii naistel kui meestel sääremähised ja jalarätid. Naised on kandnud ka kootud sääriseid ja kapukaid, mehed linasest riidest sääriseid koos jalarättidega. Piduliku rõivastuse juures kandsid nii mehed kui naised sukki. (Voolmaa 1962: 225-226; Voolmaa 2013)

Käes kandsid naised ja mehed varrastel kootud kirikindaid. Alates 19. sajandi teisest poolest on naised vähesel määral kandnud koekirjalisi sõrmkindaid.

Iisaku poluvertsikud ei tundnud käiseid ega pikitriibulist seelikut. Nad kandsid valget linast pikkade varrukatega särki, mille püstkrae, rinnaesine ja varrukate ülaosa kaunistati värvilise ristpistes tikandiga, ning särgi peal umbkuube. Abielunaiste peakatteks oli pearätik. Meeste särgid sarnanesid vene omadega ning neid kanti vöötatult valgest linasest riidest pükstel. Ülerõivaks oli nii meestel kui ka naistel valge linane rüü, talvel lambanahkne kasukas. Jalad mähkisid mehed ja naised jalarättidega, mis suvel olid valged linased, talvel mustad villased. Jalanõudeks olid pastlad. (Voolmaa 2013: 67-69)

Nagu kogu Eestis, nii hakkas ka Virumaal 19. sajandi keskel traditsiooniline rahvarõivas kasutuselt taanduma. Varem kui naistel, muutus rõivastus meestel, nad hakkasid põlvpükste asemel kandma pikki pükse ja vati asemel pintsakut. Meeste jalanõudena levisid säärsaapad, sajandi lõpul tulid kasutusele kamassid. Säärsaapaid valmistasid kohalikud kingsepad, aga rohkesti osteti neid laatadelt. Paljudel laatadel müüdi Vasknarvas ja selle ümbruses valmistatud säärsaapaid. (Voolmaa 2013: 70)

Virumaa naised on 19. sajandi teisel poolel kandnud kohati põikitriibulisi ja ruudulisi seelikuid. Põikitriibulistel seelikutel olid ülaosas kitsad, allosas laiad triibud. Ruudulised seelikud olid värvli juurest volditud või kroogitud ning neid on kokku õmmeldud pihaga. Saadi kleit, mida nimetati kaapotkleidiks. Selle põhiline kandmise aeg oli 1860.-1870. aastatel. Samal ajal oli ülerõivaks villasest sinisest riidest kaapotkuub, mis lõikelt sarnanes kaapotkleidiga. (ERKL: 52) 
Rahvarõivaste peakatetest kanti pottmütsi mõnel pool veel 20. sajandi algulgi. 19. sajandi lõpul tulid nii meestel kui naistel kasutusele vateeritud palitud.

Et koid riidesse ei läheks, korjati ja kuivatati suvel koirohtu ja kuivatatud koirohi pandi villaste riideesemete vahele. Ka kuivatatud tubakalehti pandi koide tõrjeks riiete vahele. Suvel ilusa kuiva ilmaga pandi villased riideesemed õue nöörile tuulduma - ikka koide vastu igaks juhuks. Riiet hoiti ja hooldati igati, sest uue riide valmistamine ei olnud mitte kerge (Haljala).

\section{Kodukäsitöö}

Meeste koduseks käsitööks on olnud enam puutöö, aga nad parkisid ka, valmistasid pastlaid, köisi, ajasid tõrva ja tökatit ning vähesel määral tegid sepatööd. Põhiline rauatöö tehti kutseliste seppade poolt. Meeste puutööriistadeks olid kirves ja nuga, puud siluti voolmete ja liimeistriga, auke puuriti oherdite, vinnalde, käämrite, vurr- ja vibupuuriga. Kasutusel olid ka peitlid. Kuigi saagi on talurahvas tarvitanud juba enne 19. sajandit, levisid mitmesugused saed 19. sajandi teisel poolel. Kodus tehti adrad, äkked, rehad, vikatite ja hangude varred, kühvlid, naiste käsitööriistad: hasplid, kerilauad, koonlalauad, aga ka söögi- ja jooginõud ning paljud muud tarbeesemed. (Viires 1960: 24-67)

Lihtsamaks puunõude valmistamise viisiks oli nende õõnestamine ühest toorest puutükist. Õõnestamiseks kasutati nuga, peitlit, künakirvest, tarutuura, voolmeid ja lusikanuga. Valmistati kausse, kulpe, lusikaid, looma-, leiva-, vee- ning pesukünasid, mesilaste tarusid, lasse, lähkreid, tünne ja tõrsi. (Moora 1964: 223-235)

Puukausse õonestati alguses peitliga, pandi siis tulised söed sisse, puhuti peale, kaabiti vahetevahel põlevat sütt pussiotsaga ehk rauatükiga; kui paks - pandi söed uuesti kokku ja põletati edasi (Viru-Jaagupi).

Rohkem oskusi, millega iga mees hakkama ei saanud, nõudis laudnõude (piimapütid, tünnid, lähkrid, vaadid, õlleankrud, kapad) ja painutatud kerega nõude (külimitud, sarjad, vakad) valmistamine. Puunõusid, regesid ja vankreid müüdi laatadel. Olenes talumehe oskusest ja võimalustest, mida ta kodus tegi või mida ta teha lasi või ostis.

19. sajandi teisel poolel ja 20. sajandi algul oli Eestis suuremaks puunõude valmistamise keskuseks Põhja-Tartumaa Avinurme vald, kus tehti ka regesid, looki, katusepilpaid, toole jm. Avinurme piirnes Tudulinna vallaga, kus valmistati kaldvokke, aga ka saane ja Kunda tsemendivabrikule tünnivitsu. Puutöö 


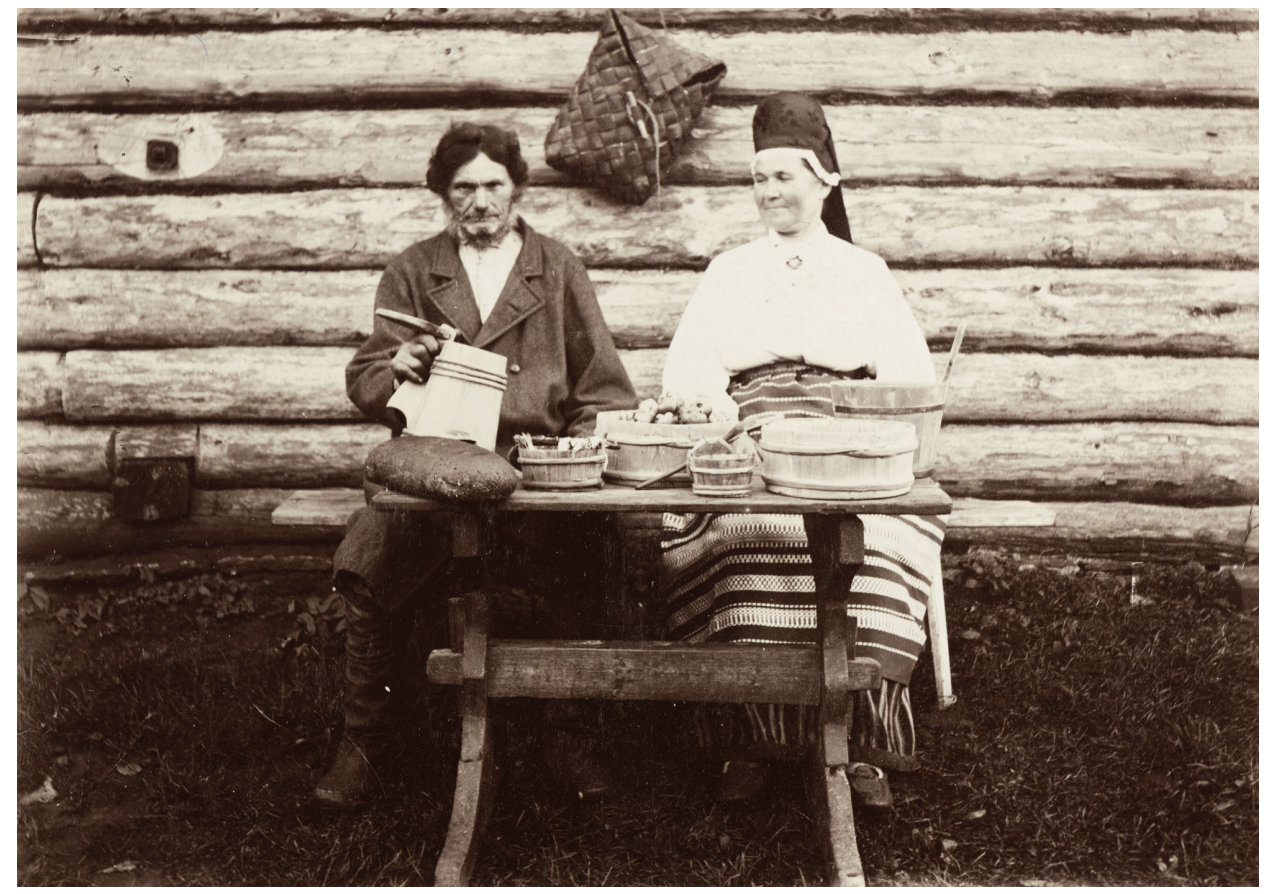

Foto 8. Mees ja naine väljas söögilaua taga.

20. sajandi algus. Virumaa põhjarannik. Fk 182:1.

oli arenenud kodutöönduseks. Tudulinna vallas valmistati kõige enam vokke Sahargu külas, aga vokimeistrid olid ka Metskülas, Pärnikul, Tudulinnas, Kellassaares, Kruusojal ja Lemmakus. Vokke tehti põllutöö kõrvalt, müüdi laatadel Viru-, Järva-, Tartu- ja Harjumaal ning Peipsi taga Venemaal. (Moora 1964: 223-235; Viires 1960: 225-249)

Vanemad hangud olid puust, harudeks oksatüükad. 19. sajandi lõpul tulid kasutusele raudhangud, millele tehti puuvarred.

Kevadel enne heinaaega tuuakse rehavarred kuivama. Võetakse noored kuused, sel ajal kui koor on hästi lahti, ja saetakse ots lõhki (tüviku poolt) ning pannakse puupulk vahele, mis otsad laiali hoiaks. Niiviisi päikese käes seisnud, kõlbab neile varsti rehad otsa teha. Reha ise tehakse suuremjagu kasest või ka vahtrast ja saarest. Viimastest saab raske reha. Pulgad rehale tehakse sitkest puust, enamasti kuslapuust, aga ka pihelgast, saarest ja eriti hääd saavad sirelist (Iisaku).

Korve tehti männijuurtest, paju- ja toomingavitstest, Alutagusel ka peergudest.

Männijuuri kisuti korvide jauks. Tehti kartuli- ja villakorvisi. Juured kooriti ära, jämedamad aeti lõhki ja kohe toorelt tehti korviks [---]. Kartu- 
likorvid on kõige parem teha pajuvitstest ja lõhestatud toomingavitstest. Pajune on raskevõitu, aga toomingane on vastupidav ja kerge. Pajuvitsad korvideks peab võtma vesipajult, teised on rabedad. Kõiki vitsu on hea vees hoida enne korvitegemist, siis läheb sitkemaks (Iisaku).

19. sajandi viimasel veerandil hakkas talurahvas rohkem tarvitama tislerite valmistatud mööblit, kingseppade tehtud jalanõusid, rätsepate õmmeldud rõivaid. Rohkem osteti potisetude savinõusid. Poodidest ja rändkaupmeestelt sai plekkämbreid ja -lüpsikuid.

Naiste kodukäsitööks oli põhiliselt tekstiilesemete valmistamine. Materjaliks oli vill ja lina. Vill tuli enne ketramist kraasida, lina ropsida ja harjal sugeda. Sügisel asus naispere ketrama. (EA V: 150-165)

Vanasti käisid nooremad tüdrukud talveõhtutel kuskil peres koos ketramas. Kui kodune talitus ära, võttis igaüks oma voki selga ja läks nn. ehale. Seal aeti juttu, lauldi ja kedrati kuni hommikuni. Vahel tulid ka küla noormehed tüdrukutele seltsi (Simuna).

Naiste üheks tööks oli värvimine. Vill värviti kas lahtiselt või lõngana, lina ainult kedratult. Valmisriiet tavaliselt ei värvitud - see võis jääda laiguliseks. Põlvest põlve on värvitud taimevärvidega.

Kanarbikukeedisega värviti villa ja lina roheliseks, karikakra õitega kollast, kivisamblaga pruuni (villale), seapohlavartega halli, lepakoorega kollakat ja pruuni, kasekoortega pruuni, kaselehtedega kollast, sibulakoortega pruuni (Haljala).

Ülalnimetatud on vaid mõned moodused. Värvi kinnitamiseks kasutati parkivaid aineid - maarjajääd, silmakivi ehk vasevitrioli, kübaramusta ehk rauavitrioli ning lisaainena soola, äädikat, kalja, õlut jm. Sinise värvi saamiseks on ostetud indigot, aniliinvärvid levisid 19. sajandi teisel poolel. (EKRL 2007: 368)

Et lõngast kangas saaks, tuli palju tööd teha: lonng haspeldada, kerasse kerida, kehale ajada, käärida, telgedele üles vedada, kududa. Kangast kooti tavaliselt kevadtalvel. (Astel 1968: 249) Kangaspuud olid rehetoas ukse läheduses, et päevavalgust saada. Kui rehetoas olid aknad, siis olid kangaspuud akna all. Kui kambrid muudeti köetavaks, pandi kangaspuud sinna. Vanemad kangaspuud olid kitsad, 19. ja 20. sajandi vahetusel tulid kasutusele nn soome teljed, millega saab kududa laiemat kangast. Kui 19. sajandi teisel poolel tekkisid põllumeeste seltsid, korraldati seal ka kangakudumise kursusi, kus naised õppisid kudumistehnikaid.

Villaseid kangaid vanutati, mis tegi need paksemaks ja tihedamaks, linased kangad pleegitati. Linane kangas pesti tuhaleelisega, seejärel peksti kurikatega pehmemaks ning hautati kuumas vees koos lehtpuutuhaga. Hautatud kangad uhuti suures vees puhtaks, laotati nädalaks pleekima. Pärast seda hautati 
kangast uuesti ning pandi jälle nädalaks pleekima. Kangaid pleegitati kolm nädalat ning seda tehti kas lume peal või murul. (Astel 1968: 252) Pleegitatud linane kangas vaaliti vaalikurika ja -kaikaga siledaks.

Rõivaste õmblemine oli naiste töö, aga külades oli ka rändrätsepaid, kes 19. sajandi esimesel poolel õmblesid pikk-kuubesid, kasukaid, meeste vatte ning pükse ja naiste kampsuneid. 19. sajandi teisel poolel hakkasid rätsepad kasutama õmblusmasinaid. Sajandi lõpul muretseti neid ka taludesse. Linnamoele üleminekul õmblesid naiste rõivaid ka naisõmblejad, aga naiste pikk-kuubi (hiljem palituid) ja kasukaid õmblesid edasi rätsepad.

Peale kehakatete valmistamise oli naiste koduseks käsitööks sõidu- ja voodivaipade valmistamine, vaipu lasti kududa ka kangrutel. Kadrinast on teada kaunite vaipade kuduja Mall Tombach (1799-1872). Vaipu on kaunistatud vöödiliste, naast- ja pindpõimes mustritega. 19. sajandi vaipadest väärivad esiletõstmist Virumaale iseloomulikud valgepõhjalised siniste vöödiliste kirjadega ning Kadrina-Haljala naastpõimelised vaibad, mis koosnesid suurest keskväljakust ning seda ümbritsevast poordist.

Vaipu hakkas talurahvas vooditekkidena kasutama siis, kui rehielamu kambrid muudeti köetavaks või elamu ehitati rehest lahku. Varem magati ülerõivaste all. 19. ja 20. sajandi vahetusel levisid vateeritud tekid.

Akna eesriided tulid tarvitusele üksik juhul juba läinud [19.] sajandi lõpul. Need olid tihti kodus kootud, üksik juhul ka poest ostetud. Neil

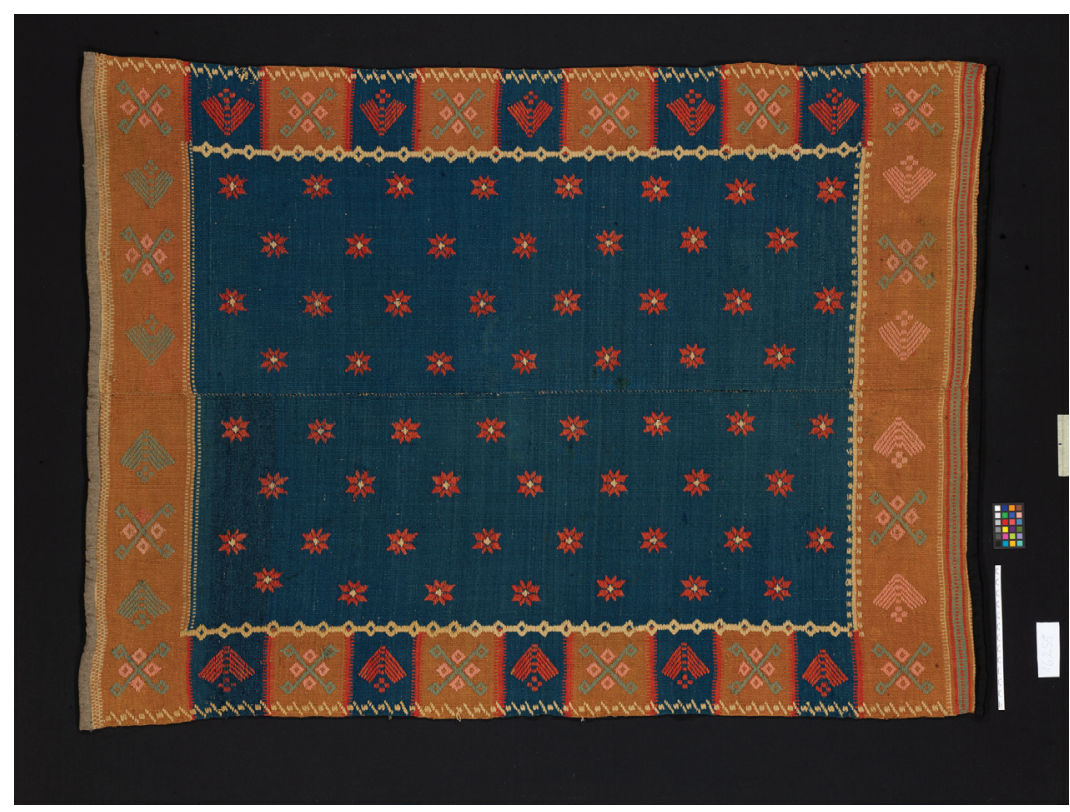

Foto 9. Vaip, kudunud Mall Tombach. Kadrina khk. ERM 16255. 
oli servas kodus kootud pitsid ja hiljem olid ka mõnel pool juba kodus heegeldatud pitskardinad. Põrandariided tulid kasutusele veidi hiljem. Ka need olid kodus kootud. Suuremalt jäult olid need põik triibulised ja triibud olid neil kaltsu ribadest. Pikitriibulised olid aga harilikult kokku keeratud takusest lõngast. Neil oli keskel põhi tumedamast lõngast ja triibud servas heledamad. Seinavaipade tarvitus tuli aga märksa hiljem selle [20.] aastasaja esimesel kümnel (Viru-Jaagupi).

Virumaa kuulub Põhja-Eesti rahvakultuuri valdkonda, kus ainelise kultuuri iseloomulikeks nähtusteks võib pidada Põhja-Eesti tüüpi rehielamut, kurgedega harkatra, naiste pikitriibulist seelikut, käiseid ja pottmütsi. Kui Eesti rahvakultuuris esinevad lääne- ja idapoolsed mõjud, siis Virumaa on idapoolsete mõjutustega. Eriti Ida-Virumaal on märgatavad vadja-isuri-vene mõjud. Samal ajal on Virumaa põhjaosa rannikuvööndi ainelist kultuuri mõjutanud tihedad sidemed soomlastega.

\section{Lühendid}

EA - Etnograafiline arhiiv ERMis

EJ - Etnograafilised joonised ERMis

ERM - Eesti Rahva Muuseum

Fk - Fotokogu ERMis

KV - Korrespondentide vastused ERMis

\section{Käsikirjalised allikad Eesti Rahva Muuseumis}

EA 3, lk 459-702. Viru-Jaagupi. H. Schmidt. 1923.

EA 10, lk 235-308. Haljala. H. Jänes. 1925.

EA 13, lk 11-96. Iisaku. E. Kääparin. 1927.

EA 15, lk 409-870. Iisaku. H. Konso. 1931.

EA 25, lk 11-218. Viru-Jaagupi. M. Sepp. 1935.

EA 40, lk 229-647. Simuna. V. Fuks. 1939.

KV 8, lk 1077-1087. Haljala. H. Palakas. 1932.

KV 91, lk 32-79.Viru-Nigula. K. Talu. 1959.

KV 153, lk 490-533. Haljala. L. Mihkli. 1967. 
KV 190, lk 31-141. Viru-Jaagupi. H. Lepiku. 1963.

KV 417, lk 390-442. Peipsi põhjarannik. W. Jõgi. 1974.

KV 463 lk 256-268. Haljala. J. Oolmann. 1976.

\section{Kirjandus}

Astel, Eevi 1968. Naiste käsitöö aastaringne tsüklilisus (XIX sajand ja XX sajandi algus). Etnograafiamuuseumi aastaraamat XXIII. Tallinn: Valgus, lk 235-255.

EA V = Vahtre, Sulev (peatoim) 2010. Eesti ajalugu V. Pärisorjuse kaotamisest Vabadussõjani. Tartu: Ilmamaa.

ERK = Viires, Ants \& Vunder, Elle (koost ja toim) 2008. Eesti rahvakultuur. Teine, täiendatud trükk. Tallinn: Eesti Entsüklopeediakirjastus.

ERKL = Viires, Ants (koost ja toim) 2007. Eesti rahvakultuuri leksikon. 3., täiendatud ja parandatud trükk. Tallinn: Eesti Entsüklopeediakirjastus.

Moora, Harri (vast toim) 1957. Eesti rahvarõivad XIX sajandist ja XX sajandi algult. Tallinn: Eesti Riiklik Kirjastus.

Jaagosild, Endla 1972. Rukki kuivatamine põllul. Etnograafiamuuseumi aastaraamat XXVI. Tallinn: Valgus, lk 95-118.

Jaagosild, Endla 1973. Suviteravilja põllul kuivatamisest Eestis. Etnograafiamuuseumi aastaraamat XXVII. Tallinn: Valgus, lk 128-152.

Jaagosild, Endla 1978. Teraviljakoristusriistadest Eestis. Etnograafiamuuseumi aastaraamat XXXI. Tallinn: Valgus, lk 48-79.

Jaagosild, Ildike 1965. Loomade ajutisest pidamisest rehetoas. Etnograafiamuuseumi aastaraamat XX. Tallinn: Valgus, lk 87-106.

Kaarma, Melanie \& Voolmaa, Aino 1981. Eesti rahvarõivad. Tallinn: Eesti Raamat.

Karu, Ellen 1971. Suviviljapeks Eestis 19. sajandi teisel poolel ja 20. sajandi algul. Etnograafiamuuseumi aastaraamat XXV. Tallinn: Valgus, lk 185-206.

Karu, Ellen 1975. Rukkipeksust Eestis 19. sajandi teisel poolel ja 20. sajandi algul. Etnograafiamuuseumi aastaraamat XXVIII. Tallinn: Valgus, lk 92-116.

Kivisaar-Feoktistova, Liivia 1959. Eesti äkked. Etnograafiamuuseumi aastaraamat XVI. Tallinn: Eesti Riiklik Kirjastus, lk 12-67.

Kreutzwald, Friedrich Reinhold 2012. Kreutzwald Virumaa rahvarõivastest. Friedrich Reinhold Kreutzwaldi käsikiri etnograaf Aino Voolmaa kommentaaridega. Tartu: Eesti Rahva Muuseum.

Loorits, Oskar 2004. Endis-Eesti elu-olu II. Lugemispalu metsaelust ja jahindusest. Eesti Rahvaluule Arhiivi toimetused 21 (15). Tartu: Eesti Kirjandusmuuseum.

Luts, Arved 1960. Rändpüügist Eesti merekalastuses. Etnograafiamuuseumi aastaraamat XVII. Tartu: Eesti NSV Teaduste Akadeemia, lk 129-168. 
Moora, Aliise 1964. Peipsimaa etnilisest ajaloost. Ajaloolis-etnograafiline uurimus eestivene suhetest. Tallinn: Eesti Riiklik Kirjastus.

Moora, Aliise 1976. Tavandi- ja peotoidust eesti külas. Etnograafiamuuseumi aastaraamat XXIX. Tallinn, lk 47-100.

Moora, Aliise 1980. Eesti talurahva vanem toit I. Tähtsamad toiduviljad, teraroad ja rü̈̈ped. Tallinn: Valgus.

Moora, Aliise 1991. Eesti talurahva vanem toit II. Joogid, leib ja leivakõrvane. Tallinn: Valgus.

Pärdi, Heiki 2012. Eesti talumaja lugu. Ehituskunst ja elu 1840-1940. Tallinn: Tänapäev. Pajatusi $=$ Ahven, Heino (koost) 1957. Pajatusi põhjarannikult . Valimik korrespondentide murdetekste II. Tallinn: Eesti NSV Teaduste Akadeemia.

Sirvilauad. Eesti Rahva Tähtraamat 1913. Tartu 1912.

Tihase, Karl 1974. Eesti talurahvaarhitektuur. Tallinn: Kunst.

Troska, Gea 1987. Eesti külad XIX sajandil. Tallinn: Eesti Raamat.

Viires, Ants 1960. Eesti rahvapärane puutööndus. Ajalooline ülevaade. Tallinn: Eesti Riiklik Kirjastus.

Viires, Ants 1962. Materjale Eesti taluelamute arenemisest XIX sajandi lõpul ja XX sajandi algupoolel. Etnograafiamuuseumi aastaraamat XVIII. Tartu, lk 99-123.

Voolmaa, A. 1962. Täiendavaid andmeid Kirde-Eesti naiste rahvarõivaste kohta. Etnograafiamuuseumi aastaraamat XVIII. Tartu, lk 212-233.

Voolmaa, Aino 2013. Ida-Virumaa rahvarõivad 19. sajandil. Rüütel, Ingrid (koost \& toim). Ida-Virumaa rahvakultuurist. 2., täiendatud ja parandatud trükk. Rakvere-Tartu: Viru Instituut, lk 45-73.

Edgar Saar - töötas Eesti Rahva Muuseumis aastail 1971-2003 teadurina ja vanemteadurina.

edgar.saar@mail.ee

\section{Summary}

\section{Material peasant culture in Virumaa in the 19th and beginning of the 20th centuries}

\section{Edgar Saar}

Keywords: clothing, farm buildings, food, sources of livelihood, trading, Virumaa

In the 19th century, the most widely spread village type was cluster village; yet row, chain, circle, and street villages also occurred. For centuries, peasants lived in the barndwelling, which was comprised of the threshing room, threshing floor, and one or several 
chambers. In the north-Estonian type of barn-dwelling the threshing room was higher and narrower than the threshing floor. The limestone stove was near the chambers. In the threshing room the longitudinal beams were crossed by poles, which were used for drying the threshed grain in the autumn. The threshing room had simple furnishings: beds, a table, a few benches and stools. Babies slept in cradles. As outbuildings the farmyard featured a summer kitchen, a sauna, a storehouse, and a cellar, sometimes also a smithy. Water came from a well.

The main source of subsistence for Virumaa people was agriculture. They grew rye, barley, wheat, oats, as well as peas, beans, lentils, turnips, cabbages, and swedes. In the first quarter of the 19th century, potatoes were grown in the vegetable plot but in the next quarter they were already planted in fields. In the last decades of the century, potato growing became more extensive. Manure was used as fertiliser in the fields. Forked plough and harrow were the tools for tilling the land, and grain was sown by hand from the seed-basket. Most of the grain was cut with the sickle but summer crops were also cut with a scythe. Cows, horses, pigs, and chicken were grown as domestic animals. In the wintertime the main means of transport was a sledge, in the summertime a wagon. People in the area of Lake Peipus and in coastal areas were engaged in fishing. Game hunting was of negligible importance; the main region where it was practised was the forests in Alutaguse.

For centuries peasants sold their produce in towns, exchanged it or bought necessary products there. Fairs were important in peasant trading, and peddlers used to travel from village to village. Until the last quarter of the 19th century the number of village stores was rather small.

The most important foodstuff for peasants was rye bread. Everyday diet included also porridges, gruels, and soups. Meat was rare but salted Baltic herring was frequent on the table. Small beer was a regular drink, on festive occasions people also drank beer.

Men used to do woodwork, but they also tanned hides, made peasant shoes, ropes, and tar, and, to a lesser extent, also did blacksmithing. Women's main handicraft was making textiles. Wool and flax were spun into yarn and thread, which were used in weaving fabrics. Clothing for both men and women was made at home, as were also gloves, stockings, and socks.

In the second half of the 19 th and the beginning of the 20th centuries many changes occurred in folk culture: chimneys and wooden floors appeared in dwelling-houses, iron ploughs and harrows were taken into use, as well as hay and grain harvesters and threshing machines. Household and clothing items started to be bought.

Virumaa is part of northern Estonian folk culture area, which is characterised by the northern Estonian type of barn-dwelling, forked plough, women's skirts with vertical stripes, midriff blouses, and pot-shaped caps. Virumaa has been under the influence from the east, especially its eastern part (Votic, Izhorian, Russian impact). Yet, the material culture in the coastal areas of northern Virumaa has been influenced by close contacts with the Finns.

Edgar Saar worked as Research Fellow and Senior Research Fellow at the Estonian National Museum in 1971-2003.

edgar.saar@mail.ee 